\section{Revista de CIENCIAS AMBIENTALES Tropical Journal of Environmental Sciences}

Revista de Ciencias Ambientales (Trop J Environ Sci) e-ISSN: 2215-3896

(Julio-Diciembre, 2021) . Vol 55(2): 45-70 DOI: https://doi.org/10.15359/rca.55-2.3

Open Access: www.revistas.una.ac.cr/ambientales e-mail: revista.ambientales@una.ac.cr Orozco-Montoya R., Madrigal-Solís H., Vargas-Bolaños C. y Orias-Arguedas L.

\title{
Analysis of the threat of groundwater contamination in the Jacó aquifer, Central Pacific, Costa Rica
}

\author{
Análisis de amenaza de contaminación del agua subterránea en el acuífero de Jacó, \\ Pacífico Central, Costa Rica
}

\author{
Ricardo A. Orozco-Montoya ${ }^{1}$, Helga Madrigal-Solís ${ }^{2}$, Christian Vargas-Bolaños ${ }^{3}$, \\ Lidia Orias-Arguedas ${ }^{4}$
}

[Received: September 20, 2020, Accepted: February 1, 2021, Revised: February 27, 2021, Published: July 1, 2021]

\begin{abstract}
[Introduction]: In Costa Rica, more than $70 \%$ of the public drinking water supply comes from groundwater sources. In the coastal city of Jacó, on the Central Pacific Coast of Costa Rica, tourism activity is essential for economic development and groundwater represents a source for supplying tourists and residents. [Objective]: This research aims to characterize the threats of groundwater contamination to the coastal aquifer of Jacó due to human activities, based on land use analysis, characterization of potential pollution sources and, estimation of the floating population related to tourist activity. [Methodology]: An inventory of potential pollution sources was carried out through the location of human/anthropogenic activities. Potential point, diffuse and linear sources were classified based on the Pollutant Origin Surcharge Hydraulically (POSH) method, as activities with high, medium and low potential generating pollutant load (threat) [Results]: Of the total potential sources, $0.5 \%$ correspond to activities with high potential, $14.0 \%$ medium potential and $23.5 \%$ low potential, and $62.0 \%$ null potential. Out of 129 point pollution sources, $64.3 \%$ were classified as medium threat activities due to the storage and handling of potentially polluting chemicals. Although the sources of high threat are those of lesser occurrence in the study area, they can generate greater negative impacts on groundwater resources. These are located mainly in the urban area of the city where the floating population reaches more than 12000 people during the holidays, so their potential for pollutant loading could rise during this period. [Conclusions]: The results will be considered in territory planning, which seeks to reduce the probability of groundwater contamination in Jacó.
\end{abstract}

Keywords: Floating population; groundwater; land use; polluting load; potential sources; tourism.

\section{Resumen}

[Introducción]: En Costa Rica, más del 70 \% del abastecimiento público de agua potable proviene de fuentes hídricas subterráneas. En la ciudad costera de Jacó, en el Pacífico Central de Costa Rica, la actividad turística es esencial para el desarrollo económico y el agua subterránea representa una fuente para abastecimiento de turistas y residentes. [Objetivo]: Esta investigación tiene por objetivo caracterizar la amenaza de contaminación del agua subterránea en el acuífero costero de Jacó debido a las actividades humanas, por medio del análisis del uso del suelo,

1 Escuela de Ciencias Geográficas, Universidad Nacional, Costa Rica. ricardo.orozco.montoya@una.ac.cr; https://orcid. org/0000-0002-8211-6853

2 Laboratorio de Hidrología Ambiental, Escuela de Ciencias Biológicas, Universidad Nacional, Costa Rica. helga.madrigal.solis@una.ac.cr; https://orcid.org/0000-0003-4423-5592

3 Centro Nacional de Alta Tecnología, Laboratorio PRIAS, San José, Costa Rica. cvargas@cenat.ac.cr; https://orcid.org/0000-0003-0853-2047

4 Escuela de Ciencias Geográficas, Universidad Nacional, Costa Rica. lidia.orias.arguedas@una.ac.cr; https://orcid.org/0000-0002-0812-0328

\begin{tabular}{|c|}
\hline 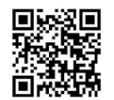 \\
\hline
\end{tabular}

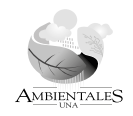




\section{Revista de CIENCIAS AMBIENTALES Tropical Journal of Environmental Sciences}

Revista de Ciencias Ambientales (Trop J Environ Sci) e-ISSN: 2215-3896

(Julio-Diciembre, 2021) . Vol 55(2): 45-70 DOI: https://doi.org/10.15359/rca.55-2.3

Open Access: www.revistas.una.ac.cr/ambientales e-mail: revista.ambientales@una.ac.cr Orozco-Montoya R., Madrigal-Solís H. Vargas-Bolaños C. y Orias-Arguedas L.

caracterización de las fuentes potencialmente contaminantes y estimación de la población flotante relacionada a la actividad turística. [Metodología]: Para ello, se realizó un inventario de fuentes potencialmente contaminantes mediante la ubicación de actividades humanas, análisis del uso del suelo y estimación de la población flotante relacionada con el turismo. Las fuentes potenciales puntuales, difusas y lineales fueron clasificadas con base en el método Pollutant Origin Surcharge Hydraulically (POSH), en actividades con alto, medio y bajo potencial generador de carga contaminante (amenaza) [Resultados]: Del total de fuentes difusas, el $0.5 \%$ corresponde a actividades con potencial alto, un $14.0 \%$ con potencial medio y un $23.5 \%$ con potencial bajo, así como un $62.0 \%$ con potencial nulo. De 129 actividades puntuales, el $64.3 \%$ se catalogaron con un potencial medio de amenaza debido a que se almacenan y manipulan sustancias químicas potencialmente contaminantes. Aunque las fuentes de amenaza alta son las de menor distribución en el área de estudio, pueden generar mayores impactos negativos al recurso hídrico subterráneo. Estas se ubican principalmente en el casco urbano de la ciudad donde la población flotante llega a más de 12000 personas en época de vacaciones, por lo que su potencial de carga contaminante podría elevarse en dicho periodo. [Conclusiones]: Los resultados serán un insumo para el ordenamiento del territorio, procurando la reducción de probabilidad de contaminación del recurso.

Palabras clave: Agua subterránea; carga contaminante; fuentes potenciales; población flotante; turismo; uso del suelo.

\section{Introduction}

On a global scale, groundwater is an important resource for socio-economic development to meet the needs of public supply, crop irrigation, livestock rearing and industrial use. In Costa Rica in 2016, groundwater represented $75 \%$ of the total number of water supply sources in the country (Herrera, 2017). Water supply sources are defined as those supplying water to the different consuming sectors, at a given rate and complying with defined quality standards (Gonçalves et al., 2019). The widespread use of groundwater for public supply responds to its proximity to the populations to be supplied, less exposure to pollution than surface water, less treatment operations required to achieve potability, less susceptible to drought and other climate-related variations, amongst others; however, the quality and quantity of groundwater may decrease due to inadequate management, mainly in coastal areas (Mahlknecht et al., 2015).

Pollution threats can be considered as the potential subsurface pollution load that can be caused at the surface as a result of various human activities and that can negatively impact groundwater (Foster et al., 2003). Given the complexity and diversity of human activities, detailed studies of these activities are difficult to address and thus, the POSH (Pollutant Origin and Surcharge Hydraulically) method was developed for the identification of those activities with the greatest potential for generating a contaminating load, based on the origin of the contaminant and its hydraulic overload (Foster et al., 2003; Hirata, 2002). This method has been used in countries such as Ecuador, Cuba, Brazil, Spain, and Argentina (Jarrín et al., 2017; Pinheiro et al., 2015).

In Costa Rica, the impact of pollution on groundwater quality has been evaluated, especially in the Central Valley (Madrigal-Solís et al., 2017; Madrigal-Solís et al., 2019). Moreover, Fonseca-Sánchez et al., (2019) and Madrigal-Solís et al., (2014) applied the POSH method in the northwestern region of the Central Valley and in a watershed in Eastern Costa Rica. In

\begin{tabular}{|c|c|c|c|c|c|}
\hline 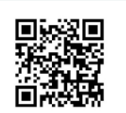 & (c) (i) $\$(0)$ & $\underbrace{}_{\text {AMBIFNAIIES }}$ & $\begin{array}{l}\frac{9 \%}{2} \\
\frac{2}{2} \\
\text { euna }\end{array}$ & 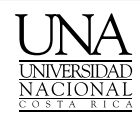 & 46 \\
\hline
\end{tabular}




\section{Revista de CIENCIAS AMBIENTALES Tropical Journal of Environmental Sciences}

Revista de Ciencias Ambientales (Trop J Environ Sci) e-ISSN: 2215-3896

(Julio-Diciembre, 2021) . Vol 55(2): 45-70 DOI: https://doi.org/10.15359/rca.55-2.3

Open Access: www.revistas.una.ac.cr/ambientales e-mail: revista.ambientales@una.ac.cr Orozco-Montoya R., Madrigal-Solís H., Vargas-Bolaños C. y Orias-Arguedas L.

another study, Orias (2011) conducted research in Costa Rica's North Pacific region on the impact of land use changes related to transnational tourism on the coast of El Coco. In the present investigation, the method was applied in a coastal and tourist area with an aquifer of different geological characteristics.

The coastal city of Jacó, on the Central Pacific Coast, has experienced the accelerated growth of a floating tourist population that adds to the resident (permanent) population. The urban expansion of the city began in the 1990s, with the unfolding of tourism as the main economic activity of the country (Orozco, 2015); currently it stands as one of the most visited beaches by national and foreign tourists. In addition, the municipality of Garabito, where the coastal city of Jacó is located, had the highest population growth rate in the country between 2000 and 2011 (reaching 4.6 \%) (National Institute of Statistics and Social Census [INEC], 2012).

The coastal aquifer of Jacó is an important source of drinking water for a large part of the resident (permanent) and floating populations despite the existence of potentially contaminating anthropogenic activities, mostly related to the tourism sector (Orozco, 2015). The aquifer in the plain has also a thin layer of soil, a water level between 0.5 and $5 \mathrm{~m}$ deep and, therefore, a medium level of hydrological vulnerability to contamination (Gómez-Cruz et al., 2019). Between 1995 and 1997, an incipient process of saline intrusion was identified (Servicio Nacional de Aguas Subterráneas, Riego y Avenamiento [SENARA], 2000), probably related to the over-extraction of groundwater. This situation led the government authority SENARA to establish restrictions for the drilling of new wells and additional efforts have been directed towards the improvement of surface water purification as a complementary resource to groundwater for public supply. In 2012, another study conducted by Sánchez-Gutiérrez et al., (2020) determined that groundwater quality, in general, was not yet affected by anthropogenic activities, except for localized contamination processes.

Given the important use of groundwater for human supply, increase of potential polluting activities due to the high annual rate of population growth of Jacó city, absence of a sanitary sewerage network and the intrinsic vulnerability to contamination of the aquifer, it is relevant to have information on the threats to which the aquifer is exposed. Thus, the objective of this research was to evaluate the threats to groundwater contamination of the coastal aquifer of Jacó, through the characterization of land use and potential pollution sources, and the estimation of the floating population caused by tourism. This information will contribute to the design of planning instruments and integrated water resource management plans to reduce the negative impact of anthropogenic activities.

\begin{tabular}{|c|c|c|}
\hline 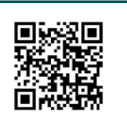 & (c) (i) (9) & 47 \\
\hline
\end{tabular}




\section{Revista de CIENCIAS AMBIENTALES Tropical Journal of Environmental Sciences}

Revista de Ciencias Ambientales (Trop J Environ Sci) e-ISSN: 2215-3896

(Julio-Diciembre, 2021) . Vol 55(2): 45-70 DOI: https://doi.org/10.15359/rca.55-2.3

Open Access: www.revistas.una.ac.cr/ambientales e-mail: revista.ambientales@una.ac.cr Orozco-Montoya R., Madrigal-Solís H., Vargas-Bolaños C. y Orias-Arguedas L.

\section{Methodology}

\subsection{Study area}

The study area, of $47.5 \mathrm{~km}^{2}$, is located in the coastal city of Jacó, in the municipality of Garabito in the province of Puntarenas, on the Central Pacific Coast of Costa Rica, between coordinates $9^{\circ} 35^{\prime} 52.17^{\prime \prime}$ and $9^{\circ} 41^{\prime} 17.24^{\prime \prime}$ north latitude, and $84^{\circ} 34^{\prime} 26.90^{\prime \prime}$ and $84^{\circ} 39^{\prime} 22.79^{\prime \prime}$ west longitude, according to the WGS84 coordinate system (Figure 1). It is composed of three micro-basins that belong to the La Mona stream and the Copey and Naranjal rivers. It has an altitude range between 0 and 750 m.a.s.l. and an average annual precipitation of $3600 \mathrm{~mm}$, with a peak in the months ranging from September to October (Solano and Villalobos, 2001).

Its geological formation is divided into two units: a) unit of alluvial and colluvial deposits and b) unit of basalts and sandstones, according to the geological map of Costa Rica at scale 1: 40000 (Denyer and Alvarado, 2007). The first unit corresponds to sedimentary materials of marine and terrestrial origin in the plain (SENARA, 2002); it presents alluvial deposits due to the dragging of materials by rivers, and colluvial deposits, which refer to deposited materials due to gravity from higher areas through erosion and water transport. The second unit is made up of fractured basalts and sandstones and corresponds to volcanic materials located in the hills and below the alluvial plain. It is made up of rocks belonging to the Tulin formation and the Nicoya Complex (SENARA, 2002).

The coastal aquifer of Jacó is composed of two types of materials. In the alluvial plain, the aquifer is unconfined and is housed in unconsolidated alluvial and colluvial materials and, thus, detritic (SENARA, 2002, Gómez-Cruz et al., 2019). In the hills, the water transits through fractured basaltic and sedimentary rocks and then heads towards the alluvial plain of the study area and, probably, integrates with the groundwater of the unconsolidated formation due to the absence of an impermeable separating barrier layer, thus uniting and becoming a single aquifer (Gómez-Cruz et al., 2019). The recharge in the alluvial plain can be produced by direct infiltration of rainfall (SENARA, 2002), by lateral contribution from the hills, and from influent rivers, in sections where the rivers provide water to the aquifer (Gómez-Cruz et al., 2019).

\begin{tabular}{|c|c|c|c|c|c|}
\hline 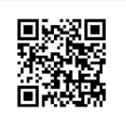 & (c) (P) & $\overbrace{\text { AMEENTILES }}$ & $\frac{1 \%}{2 \%}$ & $\frac{\text { UNA }}{\frac{\text { UNIEESIIDAD }}{\text { NACIONAL }}}$ & 48 \\
\hline
\end{tabular}




\section{Revista de CIENCIAS AMBIENTALES Tropical Journal of Environmental Sciences}

Revista de Ciencias Ambientales (Trop J Environ Sci) e-ISSN: 2215-3896

(Julio-Diciembre, 2021) . Vol 55(2): 45-70 DOI: https://doi.org/10.15359/rca.55-2.3 Open Access: www.revistas.una.ac.cr/ambientales e-mail: revista.ambientales@una.ac.cr Orozco-Montoya R., Madrigal-Solís H., Vargas-Bolaños C. y Orias-Arguedas L.

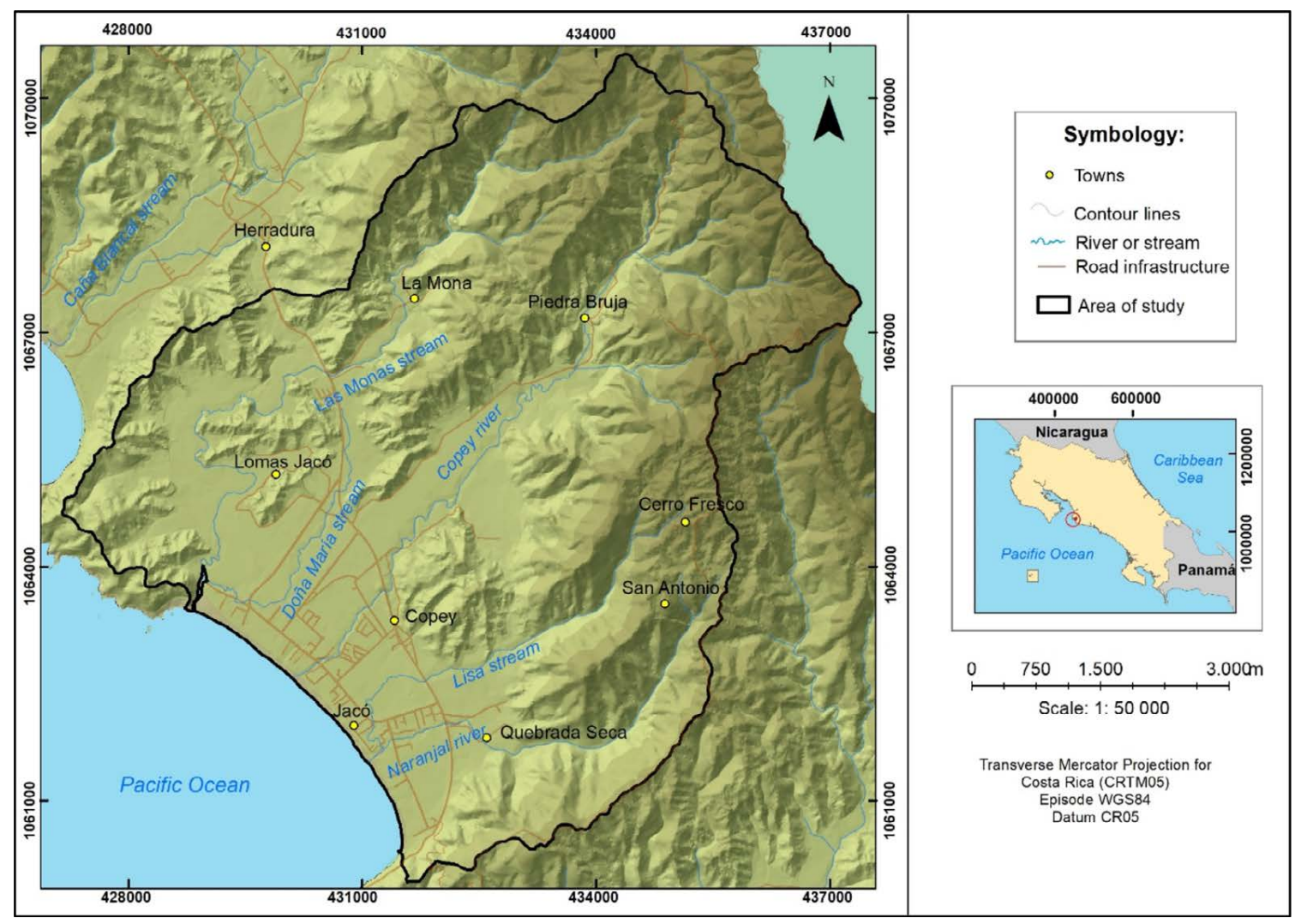

Figure 1. Study area, coastal aquifer of Jacó, Costa Rica.

Figura 1. Área de estudio, acuífero costero Jacó, Costa Rica.

The detritic aquifer, which covers $30.5 \%$ of the study area, shows a thin layer of soil, a water level between 0.5 and $5 \mathrm{~m}$ deep, a groundwater direction towards the southwest (Figure 2) and an intermediate degree of hydrogeological vulnerability to contamination (Gómez-Cruz et al., 2019). The section of the aquifer in igneous and sedimentary rocks located in the hills presents low vulnerability, mainly due to the fact that the groundwater level is between 70 and $100 \mathrm{~m}$ deep (Gómez-Cruz et al., 2019).

\begin{tabular}{|c|c|c|}
\hline 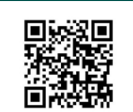 & (c) (i) (\$) & 49 \\
\hline
\end{tabular}




\section{Revista de CIENCIAS AMBIENTALES Tropical Journal of Environmental Sciences}

Revista de Ciencias Ambientales (Trop J Environ Sci) e-ISSN: $2215-3896$

(Julio-Diciembre, 2021) . Vol 55(2): 45-70 DOI: https://doi.org/10.15359/rca.55-2.3 Open Access: www.revistas.una.ac.cr/ambientales e-mail: revista.ambientales@una.ac.cr Orozco-Montoya R., Madrigal-Solís H., Vargas-Bolaños C. y Orias-Arguedas L.

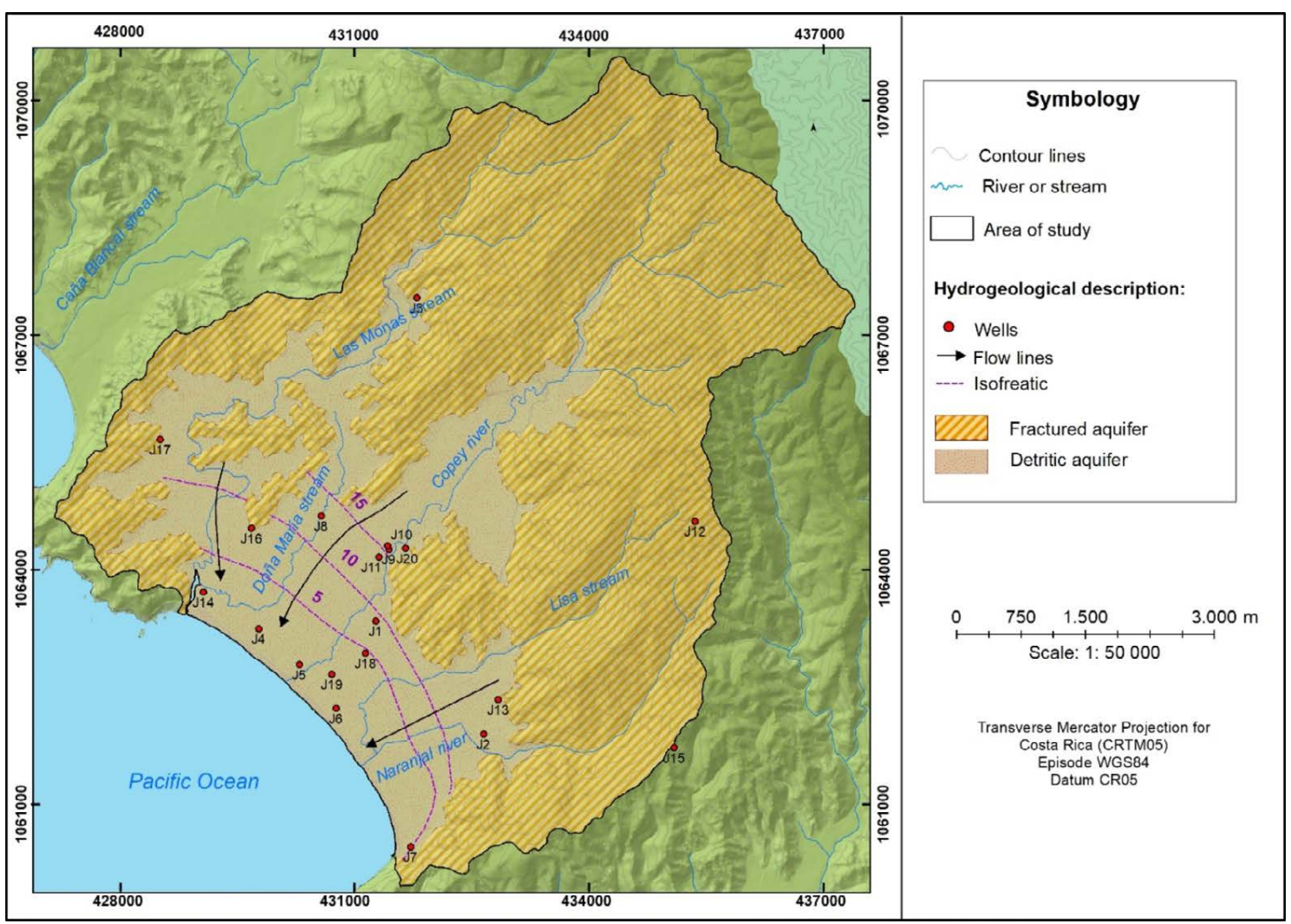

Figure 2. Hydrogeology of the coastal aquifer of Jacó, Costa Rica. Modified from: Gómez-Cruz et al., (2019). Figura 2. Hidrogeología del acuífero costero de Jacó, Costa Rica. Modificado de: Gómez-Cruz et al., (2019).

\subsection{Methodological process}

To generate the groundwater contamination threat map for the coastal aquifer of, a classification of land cover and land use data updated to the year 2019, an inventory of potential pollution sources, and an estimation of the floating population as of 2019, were carried out (Figure 3).

\begin{tabular}{|c|c|c|}
\hline 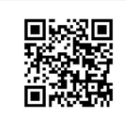 & (c) (i) $\$(0)$ & 50 \\
\hline
\end{tabular}




\section{Revista de CIENCIAS AMBIENTALES Tropical Journal of Environmental Sciences}

Revista de Ciencias Ambientales (Trop J Environ Sci) e-ISSN: $2215-3896$

(Julio-Diciembre, 2021) . Vol 55(2): 45-70 DOI: https://doi.org/10.15359/rca.55-2.3

Open Access: www.revistas.una.ac.cr/ambientales e-mail: revista.ambientales@una.ac.cr Orozco-Montoya R., Madrigal-Solís H. Vargas-Bolaños C. y Orias-Arguedas L.

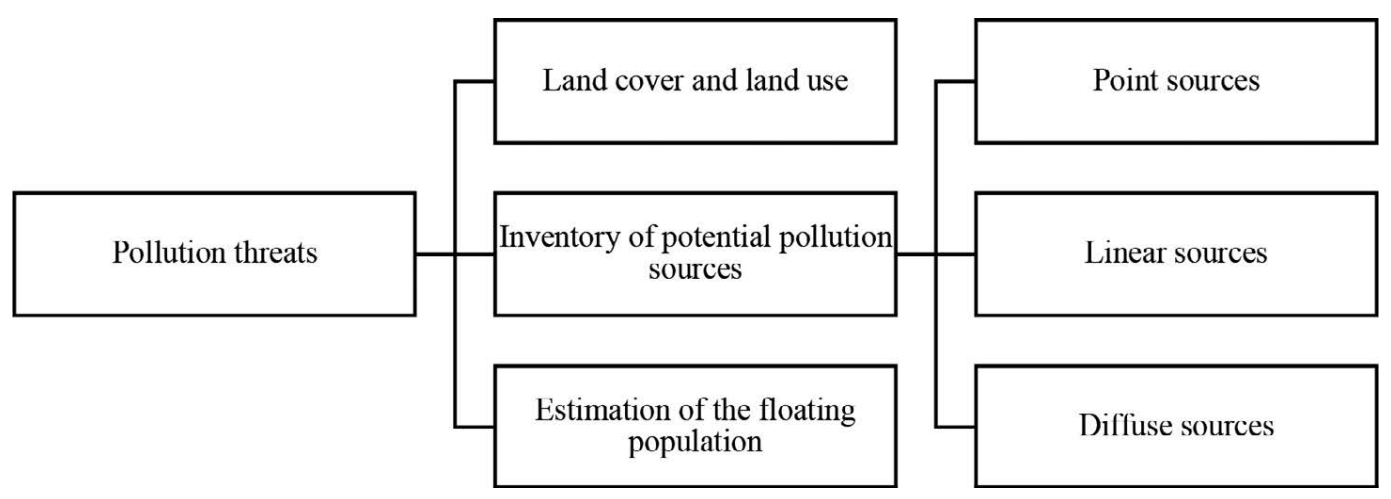

Figure 3. Structure of the methodological process applied in the investigation.

Figura 3. Estructura del proceso metodológico de la investigación.

Land cover and land use data for the year 2019 were estimated from the analysis of 2012 RapidEye satellite imagery of 5-meter pixel resolution in 5 bands distributed in the visible spectrum, and Sentinel-2 imagery captured using Sentinel No. 2 sensors of the European Space Agency's Copernicus project; the latter image is radiometrically and geometrically corrected and is of 10-meter pixel resolution. Land cover was classified into seven categories whilst land use into 18 classes (Table 1). Subsequently, a field validation of the estimated land cover and land use was performed.

Table 1. Land cover and land use categories

Cuadro 1. Categorías de cobertura y uso de la tierra

\section{Land cover}

1. Urban

2. Agriculture

3. Livestock

4. Bare ground

5. Forestry

6. Others

7. Waterbodies
1.1. Urban area

1.2. Urban green area

1.3. Recreational-Touristic Area

2.1. Annual crops

2.2. Permanent crops

3.1. Pasture

3.2. Silvopasture

4.1. Bare ground

5.1. Native forest

5.2. Riparian forest

5.3. Plantation forestry

5.4. Bushland (known in Costa Rica as charral or tacotal)

6.1. Coastal area (beach)

6.2. Road infrastructure

6.3. Solid waste disposal site/landfill

6.4. Open-pit mining

7.1. River or stream

7.2. Estuary
Land use 


\section{Revista de CIENCIAS AMBIENTALES Tropical Journal of Environmental Sciences}

Revista de Ciencias Ambientales (Trop J Environ Sci) e-ISSN: 2215-3896

(Julio-Diciembre, 2021) . Vol 55(2): 45-70 DOI: https://doi.org/10.15359/rca.55-2.3

Open Access: www.revistas.una.ac.cr/ambientales e-mail: revista.ambientales@una.ac.cr Orozco-Montoya R., Madrigal-Solís H. Vargas-Bolaños C. y Orias-Arguedas L.

The inventory of potential pollution sources included identification, spatial location, classification and characterization of anthropogenic activities in the study area. Identification and spatial location was based on the analysis of land cover and land use data corresponding to the year 2019, and cadastral and commercial information for the city of Jacó, provided by the $\mathrm{Mu}-$ nicipality of Garabito, the Ministry of Health (MS), and the Ministry of Agriculture and Livestock (MAG). The classification of potential pollution activities was carried out by the POSH method (Foster et al., 2003), which catalogues each activity according to the potential for generating contaminating loads to the aquifer at three levels: high, moderate and low (Table 2).

The POSH method was utilized in this study, which can be defined as a simplified classification tool of the potential pollution sources identified, through the possibility of the presence of the pollutant and the existence of a hydraulic overload, associating the presence of a polluting substance with a type of human activity. This method functions as a simplified hypothesis, due to the lack of information available for more detailed studies. It allows the classification of the activities representing the highest danger to groundwater quality, which tend to be associated with certain types of specific pollutants. Thus, the inventory and systematic classification of potential pollution sources constitute a fundamental step in evaluation and protection programs (Foster et al., 2003).

Potential sources were also classified, according to the POSH method, based on their spatial occurrence (Foster et al., 2003), into: a) point sources, which produce clearly defined and more concentrated contamination plumes (e.g. effluent lagoons, solid waste disposal sites, gas stations, mining activities and cemeteries); b) diffuse sources of contamination, which impact a much larger area and volume of the aquifer, e.g. urban areas without sanitary sewerage and centralized treatment, use of septic tank-leach field systems and agricultural activities and; c) linear sources, e.g. roads, where gasoline or oil spills may occur, irrigation channels and influent contaminated rivers and streams (Table 2).

Within the category of diffuse sources, pastures and silvopastures, where low amounts of agrochemicals are employed to improve the growth of grasses to sustain forage feed for extensive livestock grazing, were classified as low threat. Forest plantations, such as teak (Tectona grandis) and pochote (Bombacopsis quinate), were also classified as low threat due to the reduced application of agrochemicals compared to other crops. Permanent crops, such as small plots of fruit trees and plantains in the peripheral areas of the city, were also included in this category.

The land covered by rice fields was assigned a potential for moderate pollution load due to the moderate use of agrochemicals in rice cultivation in Costa Rica (Castillo et al., 2012); these could impact groundwater quality by the leaching of nitrates, phosphates, and the increased burden of organic matter and toxic microorganisms.

Land uses holding activities of insignificant potential contaminating loads were assigned the category of "Not applicable" (NA); this classification included urban green areas and bare ground. Land used for municipal solid waste disposal and waste pits were also categorized as NA, as these constitute point sources of pollution. Likewise, influent rivers and streams, and road infrastructure

\begin{tabular}{|c|c|c|c|c|c|}
\hline 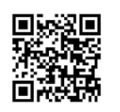 & (c) (i) (\$) & $\underset{\text { AMBENETILES }}{3}$ & $\frac{1 \%}{2 \%}$ & $\frac{\text { UNA }}{\frac{\text { UNIVERSIDAD }}{\text { NACIONAL }}}$ & 52 \\
\hline
\end{tabular}




\section{Revista de CIENCIAS AMBIENTALES Tropical Journal of Environmental Sciences}

Revista de Ciencias Ambientales (Trop J Environ Sci) e-ISSN: 2215-3896

(Julio-Diciembre, 2021) . Vol 55(2): 45-70 DOI: https://doi.org/10.15359/rca.55-2.3

Open Access: www.revistas.una.ac.cr/ambientales e-mail: revista.ambientales@una.ac.cr Orozco-Montoya R., Madrigal-Solís H., Vargas-Bolaños C. y Orias-Arguedas L.

were designated as NAs because they were classified as linear sources of potential pollution. Due to the relatively high annual precipitation, municipal solid waste landfills and/or dumpsites were categorized as point sources of high contamination potential (Foster et al., 2003).

Table 2. Classification of potential pollution sources according to the POSH method Cuadro 2. Clasificación de fuentes potenciales de contaminación según método POSH (modificado de Foster et al., 2003)

\begin{tabular}{|c|c|c|c|c|c|c|}
\hline \multirow[t]{2}{*}{ Threat level } & \multicolumn{2}{|c|}{ Diffuse sources } & \multicolumn{3}{|c|}{ Point sources } & \multirow{2}{*}{$\begin{array}{c}\text { Lineal sources } \\
\text { Urban Activities }\end{array}$} \\
\hline & $\begin{array}{l}\text { Urban residential } \\
\text { areas }\end{array}$ & $\begin{array}{l}\text { Agricultural } \\
\text { activities }\end{array}$ & $\begin{array}{l}\text { Industrial } \\
\text { activities }\end{array}$ & $\begin{array}{l}\text { Urban } \\
\text { Activities }\end{array}$ & $\begin{array}{l}\text { Mining } \\
\text { Activities }\end{array}$ & \\
\hline High & $\begin{array}{l}\text { Sanitary sewerage } \\
\text { coverage less } \\
\text { than } 25 \% \text { and } \\
\text { population density } \\
\text { over } 100 \text { people/ha. }\end{array}$ & $\begin{array}{l}\text { Intensive crops, } \\
\text { monocultures in } \\
\text { humid climates } \\
\text { with use of } \\
\text { agrochemicals, and } \\
\text { intensive grazing. }\end{array}$ & $\begin{array}{l}\text { Car repair shops, } \\
\text { pharmaceutical } \\
\text { and chemical } \\
\text { products, ice } \\
\text { factories }\end{array}$ & $\begin{array}{l}\text { Gas stations, } \\
\text { sanitary } \\
\text { landfills, } \\
\text { illegal solid } \\
\text { waste dumps }\end{array}$ & & \\
\hline Medium & $\begin{array}{l}\text { Sanitary sewerage } \\
\text { coverage between } \\
25 \% \text { and } 75 \% \text { and } \\
\text { population density } \\
\text { over } 100 \text { people/ha. }\end{array}$ & $\begin{array}{l}\text { Rice fields and } \\
\text { other annual crops. }\end{array}$ & & Laundries & $\begin{array}{l}\text { Open-pit } \\
\text { mining }\end{array}$ & $\begin{array}{l}\text { Polluted surface } \\
\text { water courses, } \\
\text { high traffic road } \\
\text { infrastructure }\end{array}$ \\
\hline Low & $\begin{array}{l}\text { Sanitary sewerage } \\
\text { coverage greater } \\
\text { than } 75 \% \text { and } \\
\text { population density } \\
\text { less than } 100 \\
\text { people/ha }\end{array}$ & $\begin{array}{l}\text { Rotation of } \\
\text { traditional crops, } \\
\text { extensive grazing, } \\
\text { ecological farms, } \\
\text { organic crops }\end{array}$ & $\begin{array}{l}\text { Food and } \\
\text { carpentry } \\
\text { factories }\end{array}$ & $\begin{array}{l}\text { Cemeteries, } \\
\text { nurseries, } \\
\text { sawmills }\end{array}$ & & $\begin{array}{l}\text { Surface water } \\
\text { courses with low } \\
\text { pollution and } \\
\text { low traffic road } \\
\text { infrastructure }\end{array}$ \\
\hline
\end{tabular}

Source: modified from Foster et al., (2003).

The characterization of potential pollution sources was conducted according to the spatial occurrence and the main types of pollutants generated in each activity, according to the methodology proposed by Foster et al., (2003). This methodology was adapted for Costa Rica following Executive Decree N³3601-MINAE-S (Presidency of the Republic of Costa Rica, 2007) (Table 3).

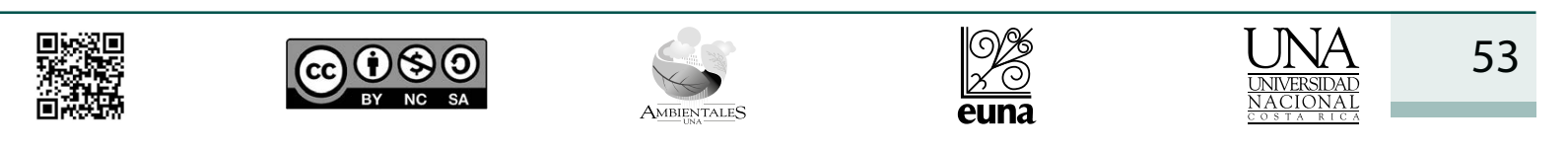




\section{Revista de CIENCIAS AMBIENTALES Tropical Journal of Environmental Sciences}

Revista de Ciencias Ambientales (Trop J Environ Sci) e-ISSN: 2215-3896

(Julio-Diciembre, 2021) . Vol 55(2): 45-70 DOI: https://doi.org/10.15359/rca.55-2.3

Open Access: www.revistas.una.ac.cr/ambientales e-mail: revista.ambientales@una.ac.cr Orozco-Montoya R., Madrigal-Solís H., Vargas-Bolaños C. y Orias-Arguedas L.

Table 3. Characteristics of the potential pollution load to groundwater

Cuadro 3. Características de la carga contaminante potencial a las aguas subterráneas

\begin{tabular}{|c|c|c|}
\hline \multirow[b]{2}{*}{ Potential sources according to land cover } & \multicolumn{2}{|c|}{ Characteristics of the pollutant load } \\
\hline & Spatial occurrence & $\begin{array}{l}\text { Major types of } \\
\text { contaminants }\end{array}$ \\
\hline \multicolumn{3}{|l|}{ Urban } \\
\hline Without sanitary sewerage (septic tanks) & $\mathrm{P}-\mathrm{D}$ & $f, o, t$ \\
\hline Leaking sewers & $\mathrm{P}-\mathrm{L}$ & $f, o, t$ \\
\hline Wastewater oxidation ponds & $\mathrm{P}$ & $\mathrm{f}, \mathrm{o}, \mathrm{t}$ \\
\hline Discharge of wastewater into the ground & $\mathrm{P}-\mathrm{D}$ & $\mathrm{f}, \mathrm{o}, \mathrm{t}$ \\
\hline Wastewater discharge into influent rivers & $\mathrm{P}-\mathrm{L}$ & $f, o, t$ \\
\hline Fuel storage tanks & $\mathrm{P}$ & $h, t$ \\
\hline Effluent ponds & $\mathrm{P}$ & $\mathrm{t}, \mathrm{h}, \mathrm{o}, \mathrm{m}, \mathrm{s}$ \\
\hline Discharge of effluents into the ground & $\mathrm{P}-\mathrm{D}$ & $\mathrm{t}, \mathrm{h}, \mathrm{o}, \mathrm{m}, \mathrm{s}$ \\
\hline Effluent discharge into influent rivers & P - L & $\mathrm{t}, \mathrm{h}, \mathrm{o}, \mathrm{m}, \mathrm{s}$ \\
\hline \multicolumn{3}{|l|}{ Agricultural } \\
\hline Cultivation with agrochemicals & $\mathrm{D}$ & $\mathrm{n}, \mathrm{p}, \mathrm{o}, \mathrm{t}$ \\
\hline Cultivation with agrochemicals and irrigation & $\mathrm{D}$ & $\mathrm{n}, \mathrm{p}, \mathrm{o}, \mathrm{t}$ \\
\hline Cultivation with application of sewage sludge & $\mathrm{D}$ & $\mathrm{n}, \mathrm{p}, \mathrm{o}, \mathrm{t}, \mathrm{s}$ \\
\hline \multicolumn{3}{|l|}{ Livestock } \\
\hline Effluent lagoon & $\mathrm{P}$ & $\mathrm{n}, \mathrm{p}, \mathrm{f}, \mathrm{o}, \mathrm{t}$ \\
\hline Discharge of effluents into the ground & $\mathrm{P}-\mathrm{D}$ & $\mathrm{n}, \mathrm{p}, \mathrm{f}, \mathrm{o}, \mathrm{t}, \mathrm{s}$ \\
\hline Effluent discharge into influent rivers & $\mathrm{P}-\mathrm{L}$ & $\mathrm{n}, \mathrm{p}, \mathrm{f}, \mathrm{o}, \mathrm{t}, \mathrm{s}$ \\
\hline \multicolumn{3}{|l|}{ Others } \\
\hline Road drainage & $\mathrm{L}$ & $\mathrm{s}, \mathrm{t}, \mathrm{h}, \mathrm{m}$ \\
\hline Accidental spills & $\mathrm{P}-\mathrm{L}$ & $\mathrm{t}, \mathrm{h}, \mathrm{m}$ \\
\hline Leaching from landfills or waste dumpsites & $\mathrm{P}$ & $\mathrm{t}, \mathrm{o}, \mathrm{m}, \mathrm{s}$ \\
\hline Alteration of hydraulic regime by drilling/excavation of mines/pits & $\mathrm{P}$ & $\mathrm{s}, \mathrm{h}, \mathrm{m}$ \\
\hline
\end{tabular}

P: Point, D: Diffuse, L: Linear, n: nitrates, p: phosphates, f: fecal pathogens, o: organic, s: salinity, h: hydrocarbons, $\mathrm{m}$ : heavy metals, t: toxic microorganisms.

Source: Foster et al., (2003) with adaptations according to Executive Decree No. 33601-MINAE-S (2007).

The floating population was classified into two types, according to the amount of time visitors stayed in the area of study: a) formal lodging tourism, which includes hotels, cabins, aparthotels, hostels, and villas, and b) informal tourism, which, for the purposes of this research, refers to the rental of rooms, houses, apartments, or condominiums for tourist lodging purposes (without being formally registered as lodging establishments in ICT [The Costa Rica Tourism Board] records). The calculation of the floating population was carried out using the method suggested by Porras (2009), which consists in quantifying the supply of lodging, assuming that in high season all lodgings are maintained at maximum capacity or occupation and in

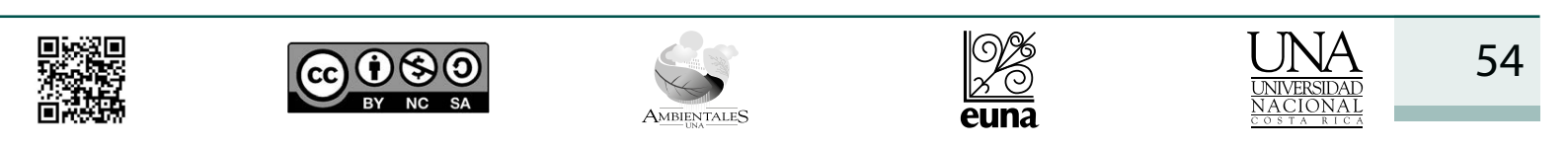




\section{Revista de CIENCIAS AMBIENTALES Tropical Journal of Environmental Sciences}

Revista de Ciencias Ambientales (Trop J Environ Sci) e-ISSN: 2215-3896

(Julio-Diciembre, 2021) . Vol 55(2): 45-70 DOI: https://doi.org/10.15359/rca.55-2.3

Open Access: www.revistas.una.ac.cr/ambientales e-mail: revista.ambientales@una.ac.cr Orozco-Montoya R., Madrigal-Solís H., Vargas-Bolaños C. y Orias-Arguedas L.

low season, maintained at medium capacity. The calculation of capacity was estimated from the number of beds available for each accommodation site and considering one bed per person.

To estimate the floating population, a survey was applied during the year 2014 to 158 lodging establishments, including hotels, cabins, condominiums, aparthotels, and apartments, which represented $90 \%$ of the total lodging establishments in the study area. Subsequently, an update was made in 2019, through fieldwork and online consultations of formal (e.g., hotels) and informal (e.g., AirBnB) accommodation websites. The high season was defined, in this study, as the period spanning from December through April and during the month of July, which coincides with the seasons of decreased rainfall and school vacations. The low season was defined for the remaining months, which coincide with the rainy season. In this study, formal and informal lodging activities were considered to be diffuse sources of pollution, because most lodging sites use the septic tank-leach field systems for wastewater disposal.

Finally, for the elaboration of the groundwater pollution threat map, ArcGIS software version 10.6.1 was used and three vectorial layers of contamination sources (e.g., punctual, linear, and diffuse) were created and integrated.

\section{Results}

\subsection{Land cover and land use}

Forest use (i.e., native forests, bushland and teak plantations) represented $62.0 \%$ of the study area (Figure 4). Native forest covered most of the area, representing $55 \%$ of the total area. It was found mainly in the northern and eastern areas of the watershed, where the fractured aquifer is located.

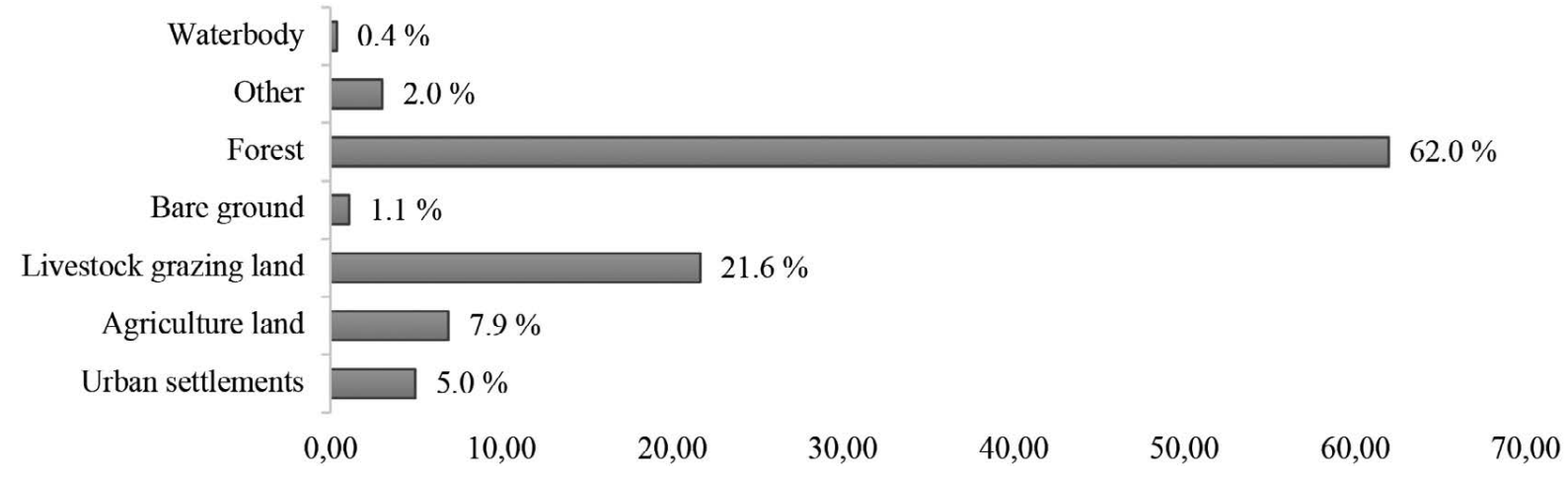

Figure 4. Estimated percent distribution of land cover in the study area of Jacó, Costa Rica, for the year 2019. Figura 4. Porcentajes de cobertura de la tierra en la zona de estudio en Jacó para el 2019.

(cc)




\section{Revista de CIENCIAS AMBIENTALES Tropical Journal of Environmental Sciences}

Revista de Ciencias Ambientales (Trop J Environ Sci) e-ISSN: 2215-3896

(Julio-Diciembre, 2021) . Vol 55(2): 45-70 DOI: https://doi.org/10.15359/rca.55-2.3

Open Access: www.revistas.una.ac.cr/ambientales e-mail: revista.ambientales@una.ac.cr Orozco-Montoya R., Madrigal-Solís H., Vargas-Bolaños C. y Orias-Arguedas L.

The second greatest land cover corresponded to livestock grazing land, where pastures and silvopastures represented $4.8 \%$ and $16.8 \%$, respectively. Pastures are located in the middle area of the basin and near the coast (Figure 5) and are mostly used for extensive rotational cattle ranching.

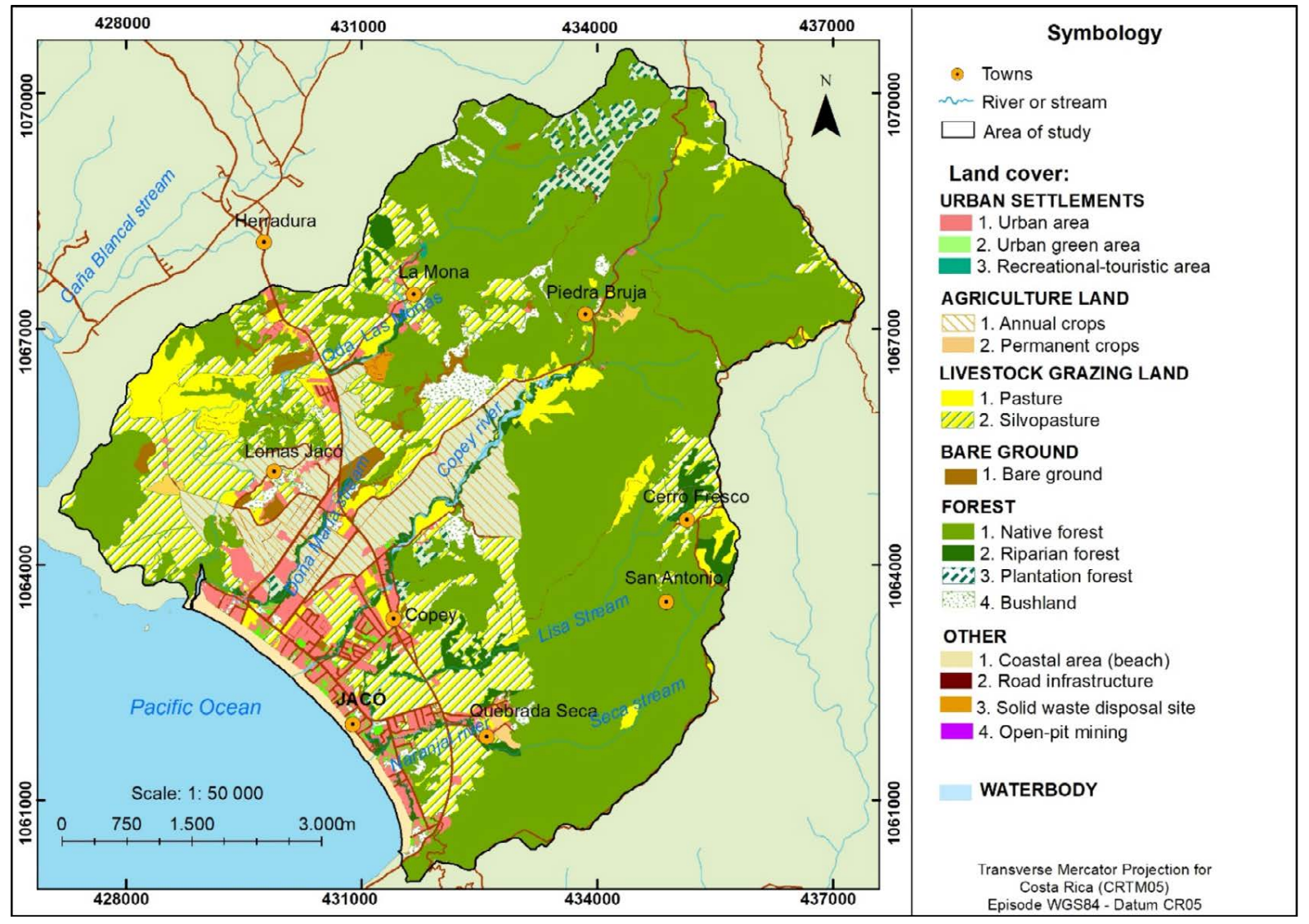

Figure 5. Land use map in the study area of Jacó, Costa Rica, for the year 2019.

Figura 5. Uso de la tierra en la zona de estudio en Jacó para el 2019.

Agriculture corresponded to the third largest activity amounting to $7.9 \%$ of all land cover, wherein rice cultivation represented $7.8 \%$ and small plots of permanent crops of fruit trees and banana plantations completed the remaining $0.1 \%$. Rice cultivation was mainly located in the alluvial plains, in the middle and lower areas of the basin (Figure 5). Urban land cover, which includes commercial activities, services, lodgings, residential areas, apartments, houses and green areas or public spaces, covered $5.0 \%$ of the study area.

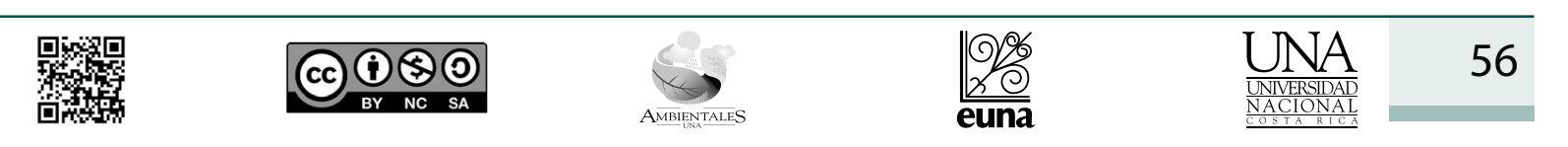




\section{Revista de CIENCIAS AMBIENTALES Tropical Journal of Environmental Sciences}

Revista de Ciencias Ambientales (Trop J Environ Sci) e-ISSN: 2215-3896

(Julio-Diciembre, 2021) . Vol 55(2): 45-70 DOI: https://doi.org/10.15359/rca.55-2.3

Open Access: www.revistas.una.ac.cr/ambientales e-mail: revista.ambientales@una.ac.cr Orozco-Montoya R., Madrigal-Solís H., Vargas-Bolaños C. y Orias-Arguedas L.

\subsection{Inventory of potential pollution sources of groundwater}

Most of the potential pollution sources were located in the city of Jacó, in the alluvial plain, over the detritic aquifer. As mentioned, it is in this area where most of the anthropogenic activities have been developed, especially along the coast.

\subsubsection{Diffuse pollution sources}

Diffuse pollution sources were related to land cover and land uses, so their counts are represented in percentages and each land use is classified into a threat category (level) according to the characteristic of its pollutant load. According to Table 4, most of the study area was classified as NA to designate those land uses that do not contain point sources with contaminating loads, which indicates the importance of forest cover in the area. The areas classified as low threat represented $23.6 \%$ of the study area, wherein pastures and silvopastures comprise the majority. Medium threat represented $13.6 \%$, which included the categories of annual crops and urban areas (Table 4). Rice cultivation was the most extensive among agricultural activities in this category.

Regarding the high threat classification, apartment towers and condominiums used as informal lodging establishments were identified as critical points. This type of infrastructure concentrates a large number of beds available to accommodate tourists and could therefore concentrate a population density greater than 100 persons/ha. Out of 49 condominiums, only 14 had a wastewater treatment plant. Additionally, two informal lodging establishments were identified in conditions of poverty, one on the banks of the Naranjal River and another very close to the left bank of the Copey River, both lacked any type of sewage disposal system.

Table 4. Diffuse pollution sources identified in the study area of Jacó, Costa Rica, for the year 2019.

Cuadro 4. Fuentes difusas de contaminación identificadas en el área de estudio en Jacó, 2019

\begin{tabular}{|c|c|c|c|c|}
\hline Land cover & Land cover & Area (\%) & $\begin{array}{l}\text { Major types of } \\
\text { contaminants }\end{array}$ & Threat level \\
\hline \multirow{5}{*}{$\begin{array}{l}\text { Urban } \\
\text { settlements }\end{array}$} & Urban area without sanitary sewerage (septic tanks) & 4.8 & $\mathrm{f}, \mathrm{o}, \mathrm{t}$ & Medium \\
\hline & Recreational Areas & 0.03 & $f, o, t$ & Low \\
\hline & Urban green areas & 0.6 & NA & NA \\
\hline & Overcrowded condominiums & 0.2 & $f, o, t$ & High \\
\hline & Informal settlements & 0.0 & $f, o, t$ & High \\
\hline \multirow[t]{2}{*}{ Agricultural land } & Annual crops & 7.8 & $\mathrm{n}, \mathrm{p}, \mathrm{o}, \mathrm{t}$ & Medium \\
\hline & Permanent crops & 0.1 & $\mathrm{n}, \mathrm{p}, \mathrm{o}, \mathrm{t}$ & Low \\
\hline \multirow{2}{*}{$\begin{array}{l}\text { Livestock grazing } \\
\text { land }\end{array}$} & Pasture & 4.8 & $\mathrm{n}, \mathrm{p}, \mathrm{f}, \mathrm{o}, \mathrm{t}$ & Low \\
\hline & Silvopasture & 16.8 & $\mathrm{n}, \mathrm{p}, \mathrm{f}, \mathrm{o}, \mathrm{t}$ & Low \\
\hline \multirow[t]{4}{*}{ Forest } & Forest & 55.0 & NA & NA \\
\hline & Riparian forest & 2.5 & NA & NA \\
\hline & Bushland (charral or tacotal) & 2.1 & NA & NA \\
\hline & Forest plantations & 1.8 & $\mathrm{n}, \mathrm{p}, \mathrm{o}, \mathrm{t}$ & Low \\
\hline
\end{tabular}

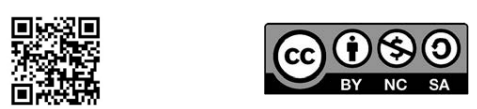

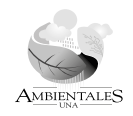




\section{Revista de CIENCIAS AMBIENTALES Tropical Journal of Environmental Sciences}

(Julio-Diciembre, 2021) . Vol 55(2): 45-70

DOI: https://doi.org/10.15359/rca.55-2.3

Open Access: www.revistas.una.ac.cr/ambientales e-mail: revista.ambientales@una.ac.cr Orozco-Montoya R., Madrigal-Solís H., Vargas-Bolaños C. y Orias-Arguedas L.

\begin{tabular}{lllll}
\hline \multicolumn{1}{c}{ Land cover } & \multicolumn{1}{c}{ Land cover } & Area (\%) & $\begin{array}{c}\text { Major types of } \\
\text { contaminants }\end{array}$ & Threat level \\
\hline Bare ground & Open land & 1.1 & $\mathrm{NA}$ & $\mathrm{NA}$ \\
Other & Coastal area & 1.1 & $\mathrm{f}, \mathrm{o}, \mathrm{t}$ & Medium \\
& Municipal solid waste disposal & 0.2 & $\mathrm{NA}$ & $\mathrm{NA}$ \\
& Road infrastructure & 0.5 & $\mathrm{NA}$ & $\mathrm{NA}$ \\
& Open-pit mining & 0.3 & $\mathrm{NA}$ & $\mathrm{NA}$ \\
Waterbody & River or stream & 0.3 & $\mathrm{NA}$ & $\mathrm{NA}$ \\
& Estuary & 0.03 & $\mathrm{NA}$ & $\mathrm{NA}$ \\
\hline
\end{tabular}

n: nitrates, p: phosphates, f: fecal pathogens, o: organic load, s: salinity, h: hydrocarbons, m: heavy metals, t: toxic microorganisms, NA: Not applicable.

Source: Foster et al., (2003) with adaptations according to Executive Decree No. 33601-MINAE-S (2007).

\subsubsection{Point and linear sources of pollution}

This study found 129 specific activities that are related to the management of hazardous waste substances, such as hydrocarbons, heavy metals, nitrates, organic load and other toxic substances (Table 5). Most of these sources were found in or around the urban area of Jacó (Figure 6). Of the identified point sources of contamination, 24 were classified as low threat, representing $18.6 \%$ of the total. This category includes materials storage warehouses and carpentry and woodworking workshops, as well as the local cemetery which, according to Foster et al., (2003), generates microbiological contamination loads in restricted areas. Also included are recreational and camping centers and greenhouses, which are generally large areas with interspersed green zones within their facilities.

Point sources with medium threat potential represented $64.3 \%$ of the total point sources in the study area. These correspond to repair shops, laundries, car washes, and commercial establishments selling chemicals, cleaning products, pharmaceuticals and paints. In these activities, potentially contaminating chemical substances, such as hydrocarbons, phenols, among others, are handled and stored. In this category, beauty centers were also found to be abundant (30 sites). In particular, beauty centers involve chemical intensive cosmetic treatments (coloring, hair smoothing and waving, cleansing, etc.) and, consequently, dispose of relatively large amounts of spent chemicals down the septic tank that can potentially leach into the groundwater; these substances are considered toxic because they contain heavy metals and other persistent organic pollutants (Schwarzenbach et al., 2006).

High threat sources were the least frequently identified, however, they represent critical pollution points. 32 sources (17\%) were identified; of these, 15 corresponded to automobile repair shops located within the urban area of the city, 6 car washes, and 11 car rental shops. In the study area, most of the auto repair shops operate without municipal control or even sanitary permits, so their effluents are mixed with domestic wastewater and disposed via septic tanks

\begin{tabular}{|c|c|c|c|c|c|}
\hline 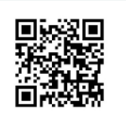 & (c) $\underset{\mathrm{BY}}{(\mathrm{NC}} \mathrm{S}$ & $\underbrace{}_{\text {AMBIFNAIIES }}$ & $\begin{array}{l}\frac{9 \%}{2} \\
\frac{2}{2} \\
\text { euna }\end{array}$ & $\frac{\text { UNA }}{\frac{\text { UNIVERSIIDAD }}{\text { NACIONAL }}}$ & 58 \\
\hline
\end{tabular}




\section{Revista de CIENCIAS AMBIENTALES Tropical Journal of Environmental Sciences}

Revista de Ciencias Ambientales (Trop J Environ Sci) e-ISSN: 2215-3896

(Julio-Diciembre, 2021) . Vol 55(2): 45-70 DOI: https://doi.org/10.15359/rca.55-2.3

Open Access: www.revistas.una.ac.cr/ambientales e-mail: revista.ambientales@una.ac.cr Orozco-Montoya R., Madrigal-Solís H., Vargas-Bolaños C. y Orias-Arguedas L.

(Orozco, 2015). Effluents contain lubricants, paints, and other discarded toxic substances, which can infiltrate and seriously contaminate groundwater (Madrigal-Solís et al., 2014).

Table 5. Point sources of pollution in the study area of Jacó, Costa Rica

Cuadro 5. Fuentes puntuales de contaminación identificadas en el área de estudio

\begin{tabular}{|c|c|c|c|}
\hline Type of activity & $\begin{array}{l}\text { Number of } \\
\text { activities }\end{array}$ & $\begin{array}{l}\text { Major types of } \\
\text { contaminants }\end{array}$ & Threat level \\
\hline Sawmill & 1 & $\mathrm{~s}, \mathrm{o}$ & Low \\
\hline Car wash & 6 & $\mathrm{~s}, \mathrm{p}, \mathrm{o}, \mathrm{h}$ & Medium \\
\hline Auto parts & 5 & $h, m, o$ & Medium \\
\hline Storage of materials and carpentry & 10 & $\mathrm{~s}, \mathrm{o}, \mathrm{m}$ & Low \\
\hline Dumpsite & 2 & $\mathrm{n}, \mathrm{p}, \mathrm{f}, \mathrm{o}, \mathrm{t}, \mathrm{s}, \mathrm{m}$ & High \\
\hline Cemeteries & 1 & o & Low \\
\hline Beauty centers & 30 & $\mathrm{~s}, \mathrm{n}, \mathrm{o}, \mathrm{p}, \mathrm{m}, \mathrm{h}$ & Medium \\
\hline Painting centers & 2 & $\mathrm{~h}, \mathrm{o}$ & Medium \\
\hline Recreation and camping centers & 5 & $f, o, t$ & Low \\
\hline Pool chemicals and equipment & 3 & $\mathrm{~s}, \mathrm{p}, \mathrm{o}, \mathrm{h}$ & Medium \\
\hline Ice factory & 1 & $\mathrm{~s}, \mathrm{~h}$ & High \\
\hline Service stations and lubricants & 3 & $\mathrm{~h}, \mathrm{~m}, \mathrm{o}$ & High \\
\hline Laundries & 5 & $\mathrm{~s}, \mathrm{p}, \mathrm{o}, \mathrm{h}, \mathrm{m}$ & Medium \\
\hline Cleaning chemicals & 1 & $\mathrm{~s}, \mathrm{p}, \mathrm{o}, \mathrm{h}$ & Medium \\
\hline Landfill & 1 & $\mathrm{n}, \mathrm{p}, \mathrm{f}, \mathrm{o}, \mathrm{t}, \mathrm{s}, \mathrm{m}$ & High \\
\hline Car rental & 11 & $\mathrm{~h}, \mathrm{~m}, \mathrm{o}$ & Medium \\
\hline Bike repair & 4 & $h, m, o$ & Low \\
\hline Human and animal health services & 11 & $o, f, m$ & Medium \\
\hline Wells and materials extraction & 3 & $\mathrm{~s}, \mathrm{~h}, \mathrm{o}$ & Medium \\
\hline Auto repair shops & 15 & $h, m, o$ & High \\
\hline Repair shops for air conditioners, appliances, refrigeration & 4 & $\mathrm{~h}, \mathrm{~m}, \mathrm{o}$ & Medium \\
\hline Stained glass window factories & 2 & $\mathrm{~m}$ & Medium \\
\hline Plant nurseries (greenhouses) and sale of agrochemicals & 3 & $\mathrm{~s}, \mathrm{o}, \mathrm{n}$ & Low \\
\hline
\end{tabular}

n: nitrates, p: phosphates, f: fecal pathogens, o: organic load, s: salinity, h: hydrocarbons, m: heavy metals, t: toxic microorganisms.

Source: Foster et al., (2003) with adaptations according to Executive Decree No. 33601-MINAE-S (2007).

\subsubsection{Linear sources of pollution}

Of the 45 linear kilometers of natural watercourses that transverse the study area, $28 \%$ were considered to have medium potential threats and $11 \%$ high potential threats, due to their short distance from point sources with medium and high pollution potential, respectively. Watercourses considered to be linear sources with low threat potential represent the remaining $61 \%$ and are located in forest and pasture areas (Figure 6). Moreover, most of the threats to groundwater contamination occurred in sections of the watercourse where groundwater has an influential behavior, namely, recharging the aquifer (Gómez-Cruz et al., 2019).

\begin{tabular}{|c|c|c|c|c|c|}
\hline 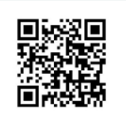 & (c) () (5) & $\bigotimes_{\text {AMBENTALES }}$ & $\frac{10 \%}{\frac{9}{2}}$ & $\frac{\text { UNA }}{\frac{\text { UNIVERSIDAD }}{\text { UNACIONAL }}}$ & 59 \\
\hline
\end{tabular}




\section{Revista de CIENCIAS AMBIENTALES Tropical Journal of Environmental Sciences}

Revista de Ciencias Ambientales (Trop J Environ Sci) e-ISSN: 2215-3896 (Julio-Diciembre, 2021) . Vol 55(2): 45-70 DOI: https://doi.org/10.15359/rca.55-2.3

Open Access: www.revistas.una.ac.cr/ambientales e-mail: revista.ambientales@una.ac.cr Orozco-Montoya R., Madrigal-Solís H., Vargas-Bolaños C. y Orias-Arguedas L.

Roads were also considered linear sources and, in general, a greater threat was ascribed to higher transit roads. In the area of study, National Highway 34 (also known as Pacífica Fernández Oreamuno Highway), Jacó City central avenue (also known as Pastor Díaz Avenue) and municipal roads (which represent $92 \mathrm{~km}$ in total), were considered to be of medium threat. This is due to the fact that the study area is a popular tourist area with high vehicular flow. The rest of the streets and roads were classified as low threat.

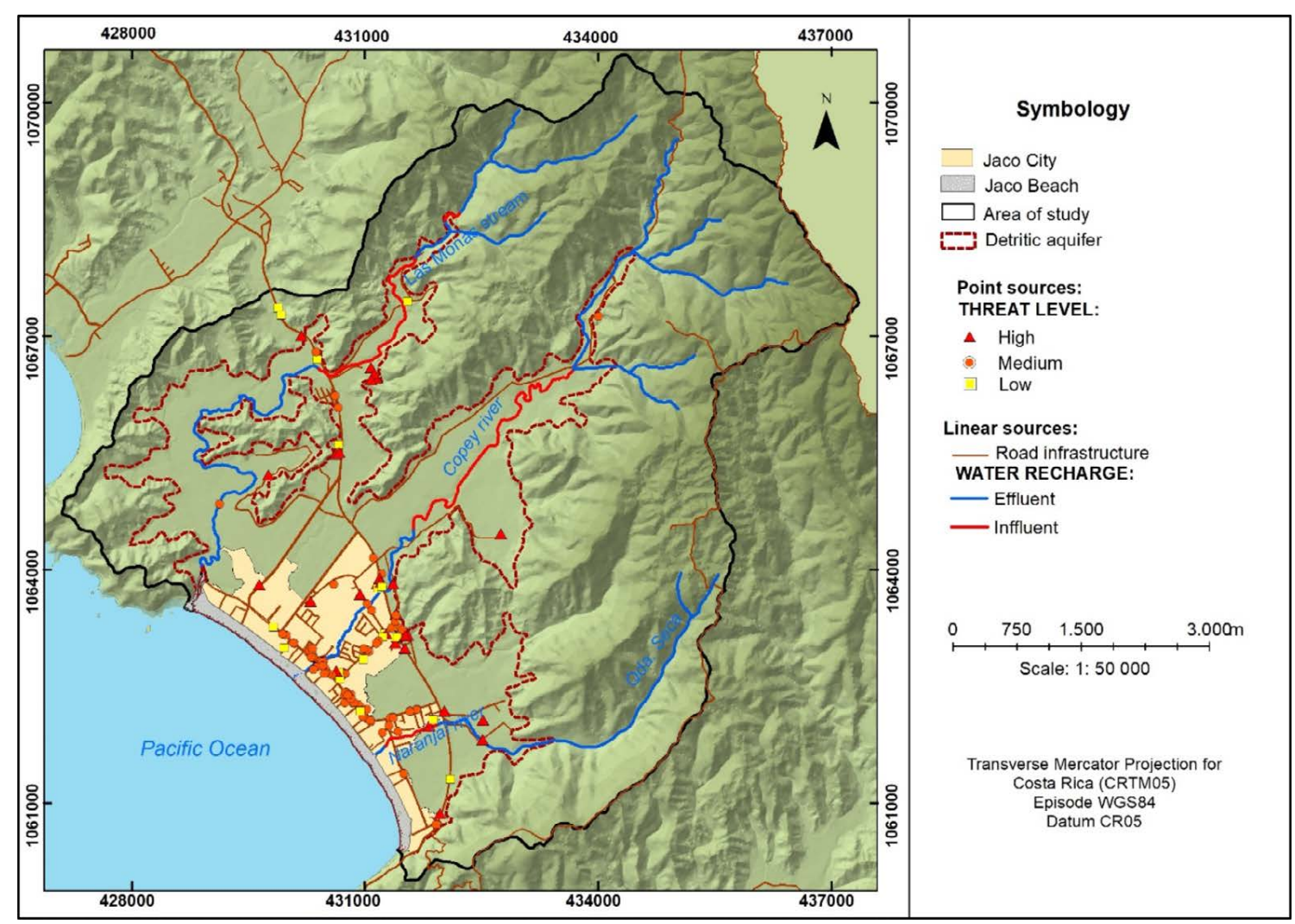

Figure 6. Point and linear sources of contamination in the Jacó basin for the year 2019.

Figura 6. Fuentes puntuales y lineales de contaminación en la cuenca Jacó para el 2019.

\subsection{Floating population in the study area}

The total number of formal lodging establishments in the study area was approximately 124, while 49 establishments were identified as informal. For each lodging establishment, the number of available beds was obtained, resulting in an estimated total of approximately 12230 available beds for tourists. Of these, some 5700 beds were estimated as belonging to formal establishments, while a little over 6500 were contributed by the informal sector. Of the total

\begin{tabular}{|c|c|c|c|c|c|}
\hline 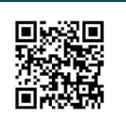 & (c) () (9) & $\overbrace{\text { AMBENTALS }}^{6}$ & $\begin{array}{l}\frac{O \%}{6} \\
\frac{2}{2} \\
\text { euna }\end{array}$ & $\frac{\text { UNA }}{\frac{\text { UNIIERSIDAD }}{\text { NACIONAL }}}$ & 60 \\
\hline
\end{tabular}




\section{Revista de CIENCIAS AMBIENTALES Tropical Journal of Environmental Sciences}

Revista de Ciencias Ambientales (Trop J Environ Sci) e-ISSN: 2215-3896

(Julio-Diciembre, 2021) . Vol 55(2): 45-70 DOI: https://doi.org/10.15359/rca.55-2.3

Open Access: www.revistas.una.ac.cr/ambientales e-mail: revista.ambientales@una.ac.cr Orozco-Montoya R., Madrigal-Solís H., Vargas-Bolaños C. y Orias-Arguedas L.

lodging establishments identified in the study area, a little more than $50 \%$ correspond to small establishments (between 26 and 75 beds), $35 \%$ to very small (between 1 and 25 beds), and $11 \%$ to medium sized (between 76 and 300 beds). Of these, only two hotels have more than 300 beds (Figure 7a). With respect to wastewater disposal, only 10 establishments have a treatment plant and the rest (114) use septic tanks-leach field systems.

a

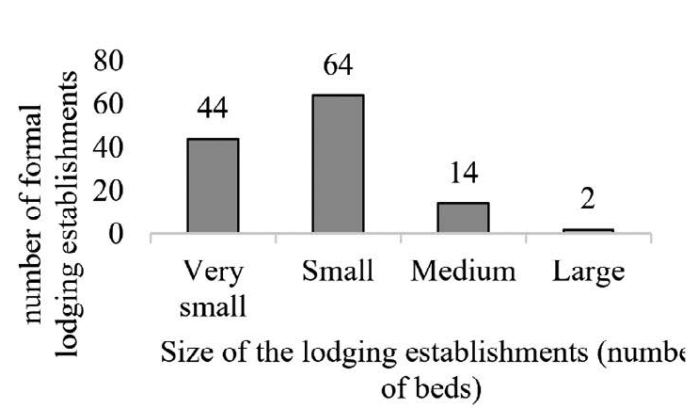

b

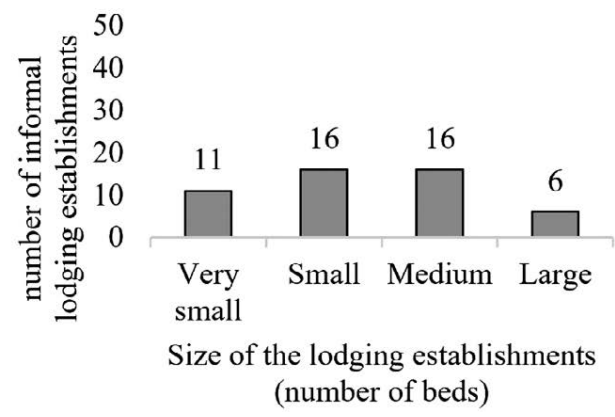

Figure 7. Accommodation capacity, according to the size (number of beds) of the lodging establishments: a) formal lodging establishments and b) informal lodging establishments.

Figura 7. Oferta de hospedaje, de acuerdo con la cantidad de camas en el área de estudio. a) Turismo de hospedaje. b) Turismo residencial.

With regard to informal tourism infrastructure, comprised by condominiums and apartments, small and medium sized establishments represented $65 \%$ of the lodging offer, with capacity between 26 and 300 beds each. It is worth noting that six establishments had more than 300 beds and 16 have more than 100 (Figure 7b). Of these types of facilities, only 14 have a wastewater treatment plant, while the all six condominiums with more than 300 beds have such treatment infrastructure.

The spatial distribution of the floating population in the area of study, according to the number of beds, assigning one bed per person, is shown in Figure 8. Thus, it can be observed that the lodging establishments with more than 300 beds are located in the western area of the city. It is precisely in this area where most of the condominiums and hotel buildings with the greatest capacity are located. In contrast, the small establishments stand out along the beach.

According to the interviews conducted, during high season the floating population reached almost 12250 people, assuming $100 \%$ occupancy at all lodging establishments. If the resident population is also added, the number of people present in Jacó during the high season may increase to approximately 17000 on a weekend or vacation day (Table 6).

\begin{tabular}{|c|c|c|c|c|c|}
\hline 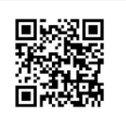 & (c) (i) (5) (O) & $\underbrace{}_{\text {AMBIFNAIIES }}$ & $\frac{1 \% \%}{20}$ & $\frac{\text { UNA }}{\frac{\text { UNIVERSIIDAD }}{\text { NACIONAL }}}$ & 61 \\
\hline
\end{tabular}




\section{Revista de CIENCIAS AMBIENTALES Tropical Journal of Environmental Sciences}

Revista de Ciencias Ambientales (Trop J Environ Sci) e-ISSN: 2215-3896

(Julio-Diciembre, 2021) . Vol 55(2): 45-70 DOI: https://doi.org/10.15359/rca.55-2.3

Open Access: www.revistas.una.ac.cr/ambientales e-mail: revista.ambientales@una.ac.cr Orozco-Montoya R., Madrigal-Solís H., Vargas-Bolaños C. y Orias-Arguedas L.

Table 6. Resident and floating population in the city of Jacó, Garabito, Costa Rica, for the year 2019

Cuadro 6. Población residente y flotante de la ciudad de Jacó, Garabito, Costa Rica, 2019

\begin{tabular}{lcc}
\hline \multicolumn{1}{c}{ Population typology } & \multicolumn{2}{c}{ Number of inhabitants } \\
& Low Season & High Season \\
\hline Resident (permanent) population & $5005^{\star}$ & $5005^{\star}$ \\
Floating population & 8560 & 12250 \\
Total & $\mathbf{1 3 5 6 5}$ & $\mathbf{1 7 2 5 5}$ \\
\hline
\end{tabular}

* Approximate resident (permanent) population for the city of Jacó, based on data collected from interviews carried out in 2014, and an estimation parameter of 3.5 people per household (INEC, 2012).

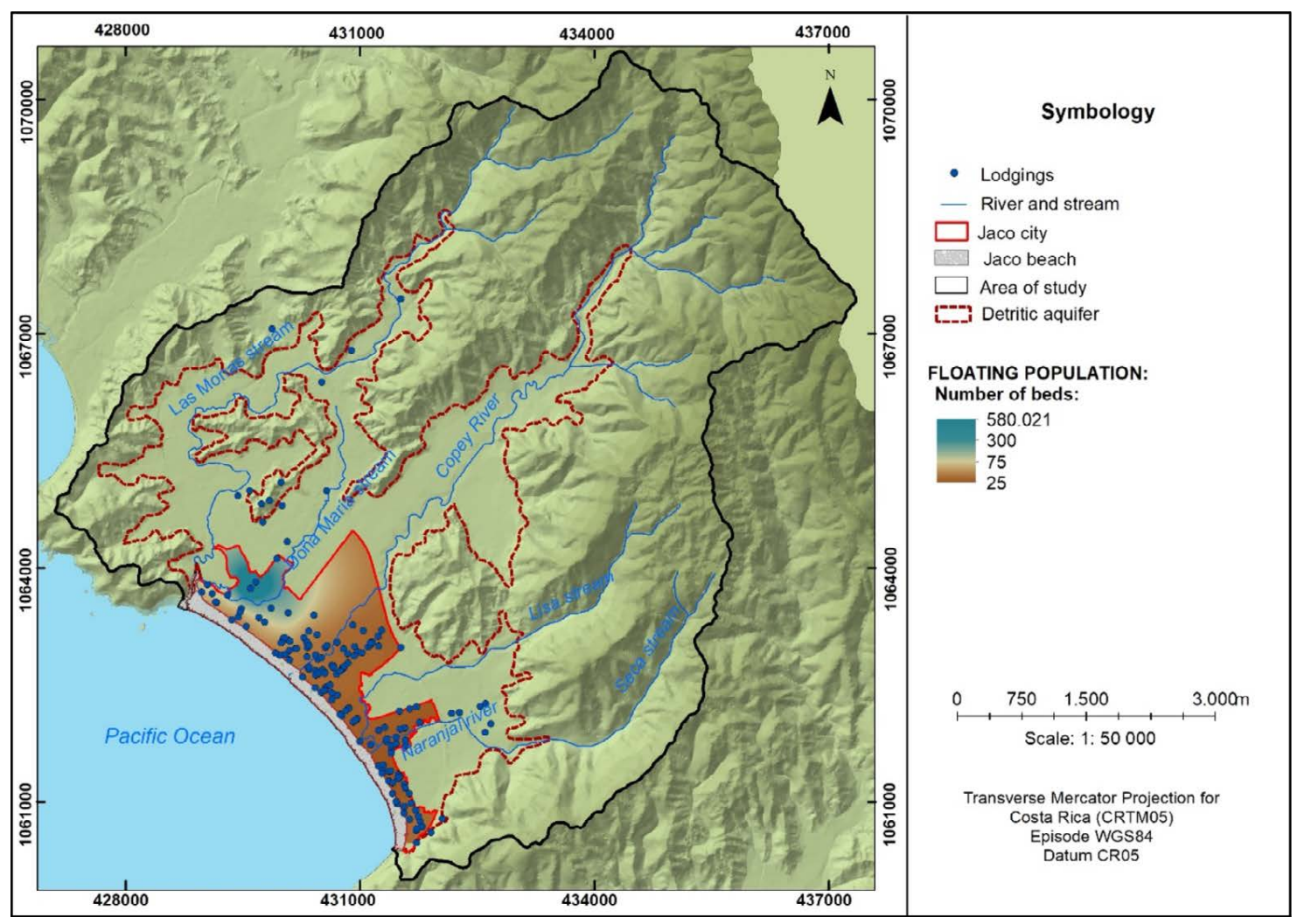

Figure 8. Estimated spatial distribution of the floating population, according to lodging establishments in the study area of Jacó, Costa Rica.

Figura 8. Distribución estimada de población flotante, según establecimientos de hospedaje en el área de estudio, Jacó, Costa Rica.

\begin{tabular}{|c|c|c|}
\hline 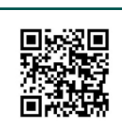 & (c) (i) (2)(2) & 62 \\
\hline
\end{tabular}




\section{Revista de CIENCIAS AMBIENTALES Tropical Journal of Environmental Sciences}

Revista de Ciencias Ambientales (Trop J Environ Sci) e-ISSN: 2215-3896

(Julio-Diciembre, 2021) . Vol 55(2): 45-70 DOI: https://doi.org/10.15359/rca.55-2.3

Open Access: www.revistas.una.ac.cr/ambientales e-mail: revista.ambientales@una.ac.cr Orozco-Montoya R., Madrigal-Solís H., Vargas-Bolaños C. y Orias-Arguedas L.

\subsection{Threat map of groundwater contamination in the coastal aquifer of Jacó}

Figure 9 shows the potential sources of diffuse, point and linear contamination, constituting the contamination threat map. The sources of high and medium threat were located mainly in the urban area of the city of Jacó, south of the basin, while the sources of low and NA threat were located north, in areas dedicated to forest cover and pastures. High threat point and linear sources of pollution were found within the urban center and surrounding areas.

In this manner, $23.5 \%$ of the study area is categorized with a low threat of contamination, $14.0 \%$ with a medium threat and $0.5 \%$ with a high threat, emphasizing $62.0 \%$ with a null potential of contaminating load generation.

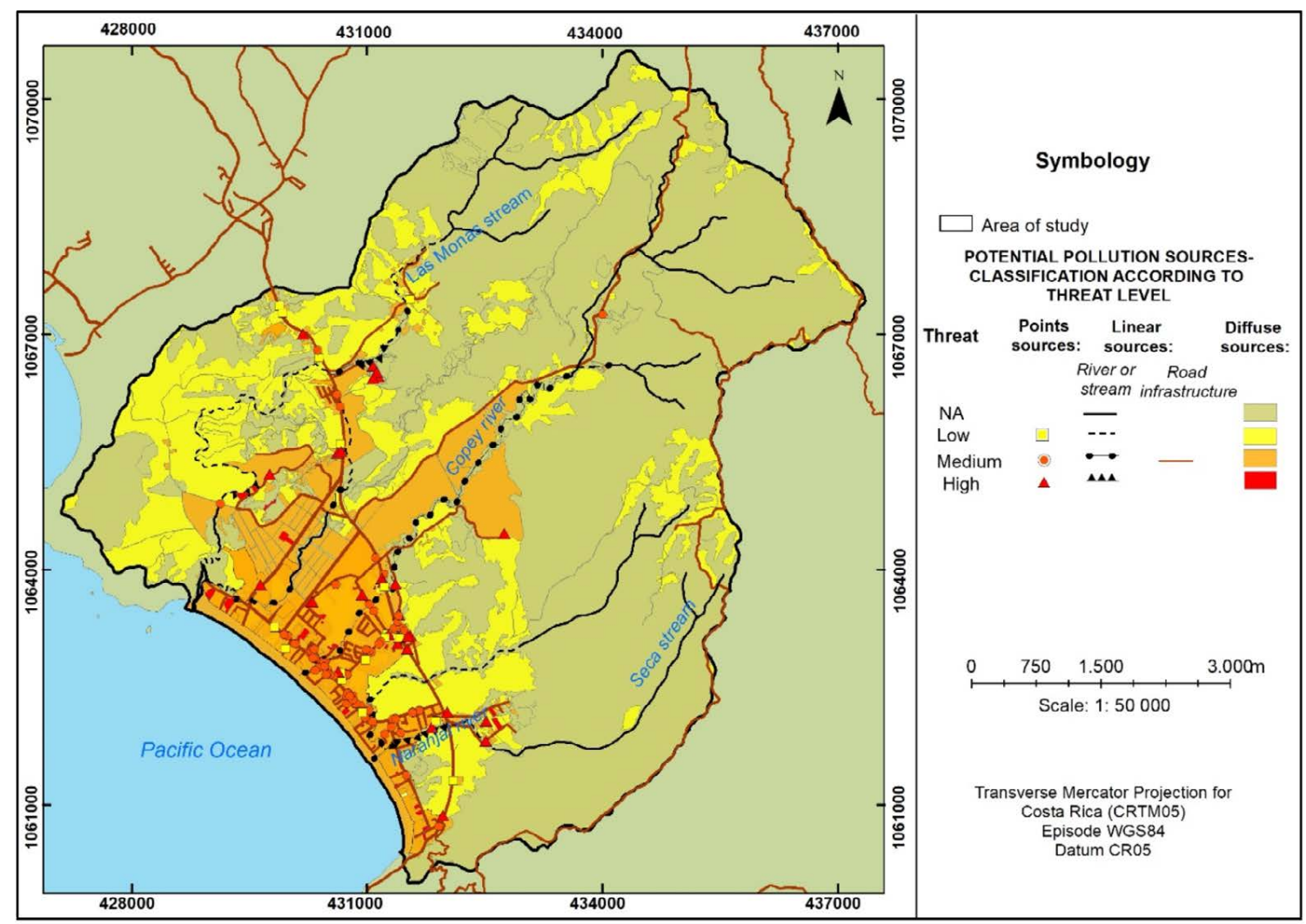

Figure 9. Pollution threat of groundwater in the coastal aquifer of Jacó, Garabito, Costa Rica.

Figura 9. Amenaza de contaminación del agua subterránea en el acuífero costero Jacó, Garabito, Costa Rica.

\begin{tabular}{|c|c|c|}
\hline 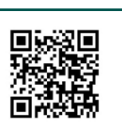 & (c) (i) (5)(2) & 63 \\
\hline
\end{tabular}




\section{Revista de CIENCIAS AMBIENTALES Tropical Journal of Environmental Sciences}

Revista de Ciencias Ambientales (Trop J Environ Sci) e-ISSN: 2215-3896

(Julio-Diciembre, 2021) . Vol 55(2): 45-70 DOI: https://doi.org/10.15359/rca.55-2.3

Open Access: www.revistas.una.ac.cr/ambientales e-mail: revista.ambientales@una.ac.cr Orozco-Montoya R., Madrigal-Solís H. Vargas-Bolaños C. y Orias-Arguedas L.

\section{Discussion}

The study area is a major tourist destination and depends, in part, on the extraction of groundwater for its operation. The aquifer is threatened by pollution sources ranging from low to high potential of generating an impacting burden on groundwater quality. The analysis of point, linear and diffuse sources of contamination, obtained through the identification of pollution sources and their classification in categories (levels) of threat using the POSH methodology, allowed to determine, spatially, the threat implied for groundwater quality of the coastal aquifer of Jacó. The use of the POSH methodology was appropriately applied in the study area to identify potential pollution sources in a delimited area-using limited available information, as was the case in the studies reported by Fonseca-Sánchez et al., (2019); Jarrín et al., (2017); Madrigal-Solís, et al., (2017); and Pinheiro et al., (2015). However, it must be considered that the threat maps generated with this methodology require constant updating due to the dynamism of the study area, which will mostly depend on the type of activities developed therein.

It is important to highlight the differences found in this research with respect to the studies of Fonseca et al., (2019) and Madrigal et al., (2014). The former was developed in a rural basin dedicated mainly to agricultural activities and, therefore, presented greater threats related to the use of agrochemicals, while the latter, being located in a peri-urban area, with extensive agricultural crops and important urban centers implementing septic tanks-leach field systems, presented diffuse sources of contamination in a more extensive manner. In the present case, our study was carried out in a coastal basin with a single urban center but presenting strong tourism activity and, thus, the dynamics regarding sources of contamination are mainly related to the temporal variation in the resident (permanent) and floating populations.

The lower part of the basin represents a critical area for the analysis, monitoring and management of potential pollution sources and groundwater quality, since the urban area and the majority of pollution sources of medium and high potential are located within this lower area. The results indicated that the potential pollution sources classified as medium and high were located mostly in the urban area of the city of Jacó, in the alluvial plain overlying the detritic section of the aquifer, which in turn presents a medium hydrogeological vulnerability to contamination (Gómez-Cruz et al., 2019). Hence, although the number of sources of high potential threat was low, they might exert a high impact on the groundwater in the area of study. This agrees with the study by Huan et al., (2018), which indicates that the harmful danger of certain specific types of pollutants plays the most important role in determining the areas of high risk of contamination of groundwater, therefore the threat must be studied from the quantification of the properties and the possible infiltrating load of pollutants.

In the urban area of Jacó, which covers approximately $23 \mathrm{~km}^{2}$, the provisions of Law No. 6043 (Legislative Assembly of the Republic of Costa Rica, 1977) on the Maritime-Terrestrial Zone (MTZ), have been waived. Consequently, an urban expansion has been undertaken whereby land use planning (zoning) has been mostly absent. Urbanism was also induced by Law No. 6512 (Legislative Assembly of the Republic of Costa Rica, 1980) that granted Jacó the

\begin{tabular}{|c|c|c|c|c|c|}
\hline 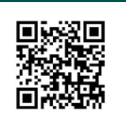 & (c) (i) (\$) & $\overbrace{\text { AMEENTIIIS }}^{S}$ & $\begin{array}{l}\frac{O \%}{2 \%} \\
\frac{20}{\text { euna }}\end{array}$ & $\frac{\text { UNA }}{\frac{\text { UNIVESIDAD }}{\text { NACIONAL }}}$ & 64 \\
\hline
\end{tabular}




\section{Revista de CIENCIAS AMBIENTALES Tropical Journal of Environmental Sciences}

Revista de Ciencias Ambientales (Trop J Environ Sci) e-ISSN: 2215-3896

(Julio-Diciembre, 2021) . Vol 55(2): 45-70 DOI: https://doi.org/10.15359/rca.55-2.3

Open Access: www.revistas.una.ac.cr/ambientales e-mail: revista.ambientales@una.ac.cr Orozco-Montoya R., Madrigal-Solís H. Vargas-Bolaños C. y Orias-Arguedas L.

title of head city of the canton of Garabito. In addition, the widespread use of septic tank-leach field systems as wastewater disposal technology was identified, and this can potentially pollute groundwater due to the leaching of contaminating loads, including bacteria, viruses, inorganic substances such as nitrate, and antibiotics and other drugs discarded through excreta.

Moreover, many of the point pollution sources were represented by beauty centers, which make intensive use of chemicals for performing cosmetic treatments (coloring, hair smoothing and waving, cleansing, etc.). Some of the substances are considered highly toxic since they contain heavy metals and other persistent organic pollutants (Schwarzenbach et al., 2006). If residues generated from beauty salon are disposed down the septic tank, they may possibly leach into the groundwater and create a serious problem. Meanwhile, the Garabito Environmental Park, used as the city's solid waste disposal dumpsite, is not equipped with all the appropriate measures for optimal waste management. According to Zumbado (2012), in the rainy season, leachate generation increases to such rate that it causes saturation of the pipes that transport the leachate to the storage pool. Thus, under heavy rain conditions the leachate is pumped and recirculated into the landfill. In addition, the landfill does not have a leachate treatment plant.

With regard to linear sources of pollution, the sections of the watercourses with the greatest pollution problems are also located within the urban area of the city, particularly, the waterbodies that transverse the city sectors where most of the hotels and commercial buildings are located. Nevertheless, sections of the watercourses can also receive contaminants from agricultural and livestock activities, sewerage and waste disposal, car washes and solid waste disposal (Mattey-Trigueros et al., 2017). It has also been determined that rivers and streams could recharge the aquifer in some sections due to existing hydraulic connections (Gómez-Cruz et al., 2019); thus, pollutants discharged into these waterbodies, with little or no pre-treatment, might percolate into the groundwater.

The research also revealed that an important percentage of the study area is dedicated to agricultural activity, mainly rice cultivation, particularly the area underlying the detritic aquifer. In this section of the aquifer, there is a medium level of vulnerability and a portion of the Copey River behaves as influent (Gómez-Cruz et al., 2019). This generates a significant potential threat due to the use of agrochemicals that, if infiltrated into the aquifer, could produce contamination by pesticides, nitrates and phosphates. In other regions of the country, there is evidence of nitrate contamination in groundwater and surface water from the use of agrochemicals associated with these crops; such is the case of nitrates found in wells near rice fields in the province of Guanacaste (Castillo et al., 2012). According to Castillo et al., (2012), rice cultivation consumes 6 to $12 \%$ of the total pesticide imports of Costa Rica. On the other hand, although $62 \%$ of the study area presented land cover and land uses that do not include an associated pollutant load, part of this area is currently private property which may potentially be developed as touristic and residential areas and thus cause future changes in land use.

Insufficient land use management has increased the unplanned growth of tourism activities, including small, medium and large-scale lodging establishments, installation of commercial

\begin{tabular}{|c|c|c|}
\hline 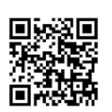 & (cc) & 65 \\
\hline
\end{tabular}




\section{Revista de CIENCIAS AMBIENTALES Tropical Journal of Environmental Sciences}

Revista de Ciencias Ambientales (Trop J Environ Sci) e-ISSN: 2215-3896

(Julio-Diciembre, 2021) . Vol 55(2): 45-70 DOI: https://doi.org/10.15359/rca.55-2.3

Open Access: www.revistas.una.ac.cr/ambientales e-mail: revista.ambientales@una.ac.cr Orozco-Montoya R., Madrigal-Solís H., Vargas-Bolaños C. y Orias-Arguedas L.

activities and services, massive real estate developments, generation of solid waste and deficient water resource protection controls. The continuous growth of the real estate sector has also generated a floating population that doubles the resident (permanent) population during the high season, which entails a series of territorial transformations that affect the landscape and the local ecosystem, increased consumption of resources, and greater quantities of solid urban waste, as well as increased soil and water contamination.

This study indicated that the size of the floating population in Jacó is similar to its resident (permanent) population. Accordingly, Garabito Municipality (2006) concluded that, on an average weekend, there are between 3000 and 5000 visitors and between 1200 to 2000 on a typical day, with $70 \%$ of the capacity of lodging establishments covered. In addition, the growing informal tourism sector in Jacó has generated an important offer for the middle and upper classes. This indicates that the city is constantly expanding and that real estate investment in tourism could lead to a growth in the floating population, even though the city does not possess a sewerage system and most of the establishments do not possess sewage treatment plants. This without considering the population visiting the city for a day, since no data was available during the investigation.

The city's planning, based on the data of resident (permanent) and floating populations, should be directed towards three key issues for the sustainable development of tourism in the area: 1) the correct management of natural resources, such as groundwater; 2) minimization of municipal solid waste generation and its adequate management; and 3) the installation of a sanitary sewerage network and wastewater treatment infrastructure to serve the needs of the urban area of the city. Therefore, the local government should implement pertinent measures to protect water resources considering that groundwater is an important resource for public health and tourism development. Some of the recommended measures include the protection of areas close to groundwater extraction sites destined for human supply, the design of protection areas around wells and springs, the generation of pollution risk mapping to determine critical areas and, the design and implementation of a monitoring network for groundwater quality.

\section{Conclusions}

The purpose of this study was to analyze the threat to groundwater contamination of the Jacó coastal aquifer by considering land use, inventory of potential polluting sources and the estimation of Jacós floating population. The POSH method allows a greater degree of detail to classify the level of threat according to the characteristics of each human activity. The validity of this method depends on the availability of data in the area of study and the prior generation of updated data such as land use characterization.

In general, the study area was characterized by important urban growth, related to the tourism sector, and agricultural activity linked to the cultivation of rice, particularly in the middle and lower parts of the study area.

\begin{tabular}{|c|c|c|}
\hline 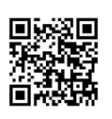 & (c) (1) & 66 \\
\hline
\end{tabular}




\section{Revista de CIENCIAS AMBIENTALES Tropical Journal of Environmental Sciences}

Revista de Ciencias Ambientales (Trop J Environ Sci) e-ISSN: 2215-3896

(Julio-Diciembre, 2021) . Vol 55(2): 45-70 DOI: https://doi.org/10.15359/rca.55-2.3

Open Access: www.revistas.una.ac.cr/ambientales e-mail: revista.ambientales@una.ac.cr Orozco-Montoya R., Madrigal-Solís H., Vargas-Bolaños C. y Orias-Arguedas L.

This study has revealed that the detritic aquifer is under a higher threat than the fractured aquifer, since the activities classified as high and medium threat have been undertaken on the former, while the fractured aquifer is influenced to a greater extent by low threat activities such as livestock rearing and forestry.

In coastal areas such as Jacó, with constantly growing, year-round tourism activity, the evaluation of the floating population and its possible impacts on the quality and quantity of groundwater consumed is highly recommended. In this case, the floating population doubles the base resident (permanent) population during the high season, and therefore, it is important to have a public policy directed towards urban planning and land management instruments, to improve the living conditions of the population and promote a sustainable tourism industry with a low water footprint.

Furthermore, it is recommended the implementation of water resource management plans to prevent and reduce the negative impact on the aquifer, considering its medium vulnerability to contamination.

\section{Ethics and conflict of interest}

The authors declare that they have fully complied with all relevant ethical and legal requirements, both during the study and in the production of the manuscript; that there are no conflicts of interest of any kind; that all financial sources are fully and clearly mentioned in the acknowledgments section; and that they fully agree with the final edited version of the article.

\section{Acknowledgements}

This study was developed within the framework of the project "Vulnerability to contamination of the coastal aquifer of Jacó and generation of inputs up to the stage of Evaluation of the System for a Water Safety Plan", SIA-0280-15, supported by the Universidad Nacional, Costa Rica (UNA). In addition, the authors would like to thank officials from the Servicio Nacional de Aguas Subterráneas, Riego y Avenamiento (SENARA) and the National Center for High Technology (CeNAT) for technical support and funding. Finally, we would like to acknowledgment the Journal and the anonymous reviewers for their insightful comments to the manuscript.

\section{References}

Castillo, L., Ruepert, C., Ramírez, F., Wendel, B., Bravo, V., \& de la Cruz, E. (2012). Plaguicidas $y$ otros contaminantes (Informe Estado de la Nación en desarrollo humano sostenible $\mathrm{n}^{\circ} 18$ ). Programa Estado de la Nación, Consejo Nacional de Rectores. San José, Costa Rica. http:// repositorio.conare.ac.cr/handle/20.500.12337/441

Denyer, P. and Alvarado, G. (2007). Mapa Geológico de Costa Rica. Escala 1: 40 000. Universidad de Costa Rica, San José, Costa Rica.

\begin{tabular}{|c|c|c|}
\hline 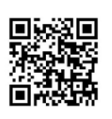 & (c) & 67 \\
\hline
\end{tabular}




\section{Revista de CIENCIAS AMBIENTALES Tropical Journal of Environmental Sciences}

Revista de Ciencias Ambientales (Trop J Environ Sci) e-ISSN: 2215-3896

(Julio-Diciembre, 2021) . Vol 55(2): 45-70 DOI: https://doi.org/10.15359/rca.55-2.3

Open Access: www.revistas.una.ac.cr/ambientales e-mail: revista.ambientales@una.ac.cr Orozco-Montoya R., Madrigal-Solís H., Vargas-Bolaños C. y Orias-Arguedas L.

Fonseca-Sánchez, A., Madrigal-Solís, H., Núñez-Solís, C., Calderón-Sánchez, H., Moraga-López, G., \& Gómez-Cruz, A. (2019). Evaluación de la amenaza de contaminación al agua subterránea y áreas de protección a manantiales en las subcuencas Maravilla-Chiz y Quebrada Honda, Cartago, Costa Rica. Uniciencia, 33(2), 76-97. https://doi.org/10.15359/ru.33-2.6

Foster, S., D'Elia, M., Hirata, R., Gomes, D., \& Paris, M. (2003). Protección de la Calidad del Agua Subterránea, guía para empresas de agua, autoridades municipales y agencias ambientales. Banco Mundial.

Garabito Municipality. (2006). Capítulo VIII: Pronóstico y problemática cantonal. In: Plan Regulador Urbano de la Ciudad de Jacó. Jacó, Garabito, Costa Rica.

Gómez-Cruz, A., Madrigal-Solís, H., Núñez-Solís, C., Calderón-Sánchez, H., \& Jiménez-Gavilán, P. (2019). Vulnerabilidad hidrogeológica en la zona costera de Jacó, Pacífico Central, Costa Rica. Revista Geográfica De América Central, 2(63), 141 - 163. https://doi.org/10.15359/ rgac.63-2.5

Gonçalves, N., Valente, T., \& Pamplona, J. (2019). Water supply and access to safe water in developing arid countries. SDRP Journal of Earth Sciences \& Environmental Studies, 4(2), 589-599. https://doi.org/10.25177/JESES.4.2.RA.497

Herrera, J. (2017). Uso y estado de los recursos: recurso hídrico. (Informe Estado de la Nación en desarrollo humano sostenible $n^{\circ} 23$ ). Programa Estado de la Nación, Consejo Nacional de Rectores. San José, Costa Rica. http://repositorio.conare.ac.cr/handle/20.500.12337/1085

Hirata, R. (2002). Carga contaminante y peligros a las aguas subterráneas. Revista Latino-Americana de Hidrogeología, 2, 81-90.

Huan, H., Zhang, B.T., Kong, H., Li, M., Wang, W., Xi, B., \& Wang, G. (2018). Comprehensive assessment of groundwater pollution risk based on HVF model: A case study in Jilin City of northeast China. Science of the total Environment. 628-629(1), 1518-1530. https://doi. org/10.1016/j.scitotenv.2018.02.130

Jarrín, A., Salazar, J., \& Martínez-Fresneda, M. (2017). Evaluación del riesgo a la contaminación de los acuíferos de la Reserva Biológica de Limoncocha, Amazonía Ecuatoriana. Ambiente e Agua - An Interdisciplinary Journal of Applied Science, 12(4), 652-665. https://doi. org/10.4136/ambi-agua.2030

Legislative Assembly of the Republic of Costa Rica. (1977). Ley No. 6043 Sobre de Zona Marítima Terrestre. San José, Costa Rica. Publication: 02/03/1977.

Legislative Assembly of the Republic of Costa Rica. (1980). Ley No. 6512 que crea el cantón de Garabito. San José, Costa Rica. Publication: 25/09/1980.

\begin{tabular}{|c|c|c|c|c|c|}
\hline 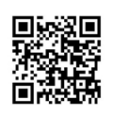 & (c) $\underset{\mathrm{BY}}{(\mathrm{NC}} \mathrm{S}$ & $\overbrace{\text { AMBIFITIISS }}$ & $\frac{1 \%}{2 \%}$ & $\frac{\text { UNA }}{\frac{\text { UNIEESIDAD }}{\text { NACIONAL }}}$ & 68 \\
\hline
\end{tabular}




\section{Revista de CIENCIAS AMBIENTALES Tropical Journal of Environmental Sciences}

Revista de Ciencias Ambientales (Trop J Environ Sci) e-ISSN: 2215-3896

(Julio-Diciembre, 2021) . Vol 55(2): 45-70 DOI: https://doi.org/10.15359/rca.55-2.3

Open Access: www.revistas.una.ac.cr/ambientales e-mail: revista.ambientales@una.ac.cr Orozco-Montoya R., Madrigal-Solís H., Vargas-Bolaños C. y Orias-Arguedas L.

Madrigal-Solís, H., Fonseca-Sánchez, A., Núñez-Solís, C., \& Gómez-Cruz, A. (noviembre-diciembre, 2014). Amenaza de contaminación del agua subterránea en el sector norte del acuífero Barva, Heredia, Costa Rica. Tecnología y Ciencias del Agua, 5(6), 103-118.

Madrigal-Solís, H., Fonseca-Sánchez, A., \& Reynolds-Vargas, J. (enero-febrero, 2017). Caracterización hidrogeoquímica de los acuíferos volcánicos Barva y Colima en el Valle Central de Costa Rica. Tecnología y Ciencias del Agua, 8(1), 115-132. https://doi. org/10.24850/j-tyca-2017-01-09

Madrigal-Solís, H., Fonseca-Sánchez, A., Calderón-Sánchez, H., Gómez-Cruz, A., \& Núñez-Solís, C. (2019). Diseño de una red de monitoreo como herramienta de gestión participativa: calidad física y química del agua subterránea en tres subcuencas del Valle Central, Costa Rica. Uniciencia, 33(1), 43-60. https://doi.org/10.15359/ru.33-1.4

Mahlknecht, J., Hirata, R., \& Ledesma-Ruiz, R. (2015). Urban Groundwater Supply in Latin American Cities: Panorama and the Cases of Mexico City and São Paulo. In I. Aguilar-Barajas., J. Mahlknecht., J. Kaledin., M. Kjellén., \& A. Mejía-Betancourt (eds.), Water and Cities in Latin America: Challenges for Sustainable Development (Earthscan Studies in Water Resource Management) (pp. 126-146). Earthscan/Routledge. England. https://doi. org/10.4324/9781315848440

Mattey Trigueros, D., Navarro Picado, J., Obando Rodríguez, P., Fonseca Sánchez, A., \& Núñez Solís, C. (2017). Caracterización de la cobertura vegetal dentro de la franja de protección del río Copey, Jacó, Puntarenas, Costa Rica. Revista Geográfica De América Central, 1(58), 275 294. https://doi.org/10.15359/rgac.58-1.11

National Institute of Statistics and Social Census [INEC]. (2012). Resultados generales X Censo Nacional de Población y VI de Vivienda 2011. https://www.inec.cr/documento/ censo-2011-resultados-generales-censo-2011

Orias, L. (2011). Propuesta de un plan de gestión ambiental de la disponibilidad del Recurso Hidrogeológico con relación al abastecimiento de agua en el espacio costero de El Coco. Carrillo, Guanacaste. Costa Rica. Revista Geológica de América Central, 45, 123-139. https://doi. org/10.15517/RGAC.V0I45.1963

Orozco, R. (2015). Propuesta de manejo de uso y cobertura de la tierra para la reducción del riesgo de contaminación del acuífero costero Jacó, Pacífico Central, Costa Rica. [Bachelor's thesis, Universidad Nacional]. http://www.hidrologia.una.ac.cr/index.php/ tesis/103-manejo-uso-cobertura-tierra

Pinheiro, R., Carvalho, A., Valli, A., and Da Silva, J.L. (2015). Aplicação dos Métodos GOD e POSH para determinação da vulnerabilidade e perigo à contaminação dos aquíferos na cidade de Santa Maria-RS/Application of the GOD and POSH methods to determine the

\begin{tabular}{|c|c|c|c|c|c|}
\hline 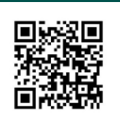 & (c) (i) (\$) & $\leftrightarrow$ & $\frac{10 \%}{\frac{\sigma}{2}}$ & 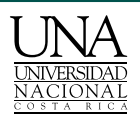 & 69 \\
\hline
\end{tabular}




\section{Revista de CIENCIAS AMBIENTALES Tropical Journal of Environmental Sciences}

Revista de Ciencias Ambientales (Trop J Environ Sci) e-ISSN: 2215-3896

(Julio-Diciembre, 2021) . Vol 55(2): 45-70 DOI: https://doi.org/10.15359/rca.55-2.3

Open Access: www.revistas.una.ac.cr/ambientales e-mail: revista.ambientales@una.ac.cr Orozco-Montoya R., Madrigal-Solís H., Vargas-Bolaños C. y Orias-Arguedas L.

vulnerability and contamination risk of aquifers in Santa M. Revista de Gestão de Água da América Latina, 12(2), 61-79. https://doi.org/10.21168/rega.v12n2.p61-79

Porras, M. (2009). El riesgo de la contaminación fecal en Jacó y su gestión. [Bachelor's thesis, Universidad Nacional].

Presidency of the Republic of Costa Rica. (2007). Decreto Ejecutivo No 33601-MINAE-S. Reglamento de vertido y reuso de aguas residuales. Diario Oficial La Gaceta $\mathrm{N}^{\circ} 55$, Alcance $\mathrm{N}^{\circ}$ 8 del 19/03/2007.

Sánchez-Gutiérrez, R., Mena-Rivera, L., Sánchez-Murillo, R., Fonseca-Sánchez, A., and Madrigal-Solís, H. (2020). Groundwater processes and water quality in a human-altered landscape in the Central Pacific coast of Costa Rica. Environ Geochem Health, 42, 2685-2701. https:// doi.org/10.1007/s10653-019-00501-5.

Schwarzenbach, R.P., Escher, B.I., Fenner, K., Hofstetter, T.B., Johnson, C.A., Von Gunten, U., and Wehrli, B. (2006) The challenge of micropollutants in aquatic systems. Science 313(5790), 1072-1077. https://doi.org/10.1126/science.1127291

Servicio Nacional de Aguas Subterráneas, Riego y Avenamiento [SENARA]. (2000). Evaluación del acuífero Jacó, cantón de Garabito, Provincia de Puntarenas. Área de aguas subterráneas. San José, Costa Rica. [Internal report].

Servicio Nacional de Aguas Subterráneas, Riego y Avenamiento [SENARA]. (2002). Evaluación del acuífero de Jaco, cantón de Garabito, Provincia de Puntarenas. pp.15. San José, Costa Rica [Internal report].

Solano, J., and Villalobos, R. (2001). Aspectos fisiográficos aplicados a un bosquejo de regionalización geográfico climático de Costa Rica. Tópicos meteorológicos y oceanográficos 8(1), 26-39.

Zumbado, L. (2012). Optimización del sistema de tratamiento de los lixiviados generados en el Relleno Sanitario del Parque Ambiental Municipalidad de Garabito. [Bachelor's thesis, Tecnológico de Costa Rica]. Retrieved from: https://repositoriotec.tec.ac.cr/handle/2238/3134

\begin{tabular}{|c|c|c|c|c|}
\hline 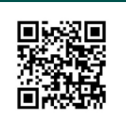 & (c) (1) & $\leftrightarrow$ & $\frac{O \%}{\text { euna }}$ & 70 \\
\hline
\end{tabular}

